\title{
PRECEDENTES E VINCULAÇÃO \\ Instrumentos do Stare Decisis e Prática Constitucional Brasileira
}

\section{Patrícia Perrone Campos Mello*}

\begin{abstract}
1. Introdução. 2. Direito Comparado. 2.1. Conceitos importantes para o manejo de precedentes. Holding. Rationale. Obiter dictum. 2.2. Distinguish. 2.3. Overruling e Overriding. 2.4. Outros aspectos relevantes para $o$ trabalho com precedentes. Relatório e fundamentação das decisōes. Educação dos advogados e dos magistrados. Tecnologias. 3. $O$ manejo de precedentes no direito brasileiro. 3.1. Regra vinculante. 3.2. Distinção entre precedente e caso a ser decidido. 3.3. Superação de precedentes. 4. Conclusão.
\end{abstract}

\section{Introdução}

A indiscutivel expansão do controle concentrado de constitucionalidade ${ }^{1}$, as recentes discussões empreendidas pelo Supremo Tribunal Federal acerca da eficácia transcendente da motivação nesta sede, e, finalmente, a criação da súmula vinculante $^{2}$, através da Emenda Constitucional $n^{\circ} 45 / 04$, apontam para um novo momento da hermenêutica constitucional.

* Procuradora do Estado do Rio de Janeiro.

1 Sobre a tendência ao alargamento da jurisdição constitucional abstrata e concentrada no Brasil e, ainda, para exame das características do controle difuso e do controle concentrado de constitucionalidade, do controle de constitucionalidade por via incidental e por via principal, bem como do caráter hlbrido do sistema brasileiro, albergando as referidas modalidades e combinando o controle por via incidental e difuso com o controle por via principal e concentrado, cf. BARROSO, Luís Roberto. $O$ controle de constitucionalidade no direito brasileiro: exposição sistemática da doutrina e análise crítica da jurisprudência. São Paulo: Ed. Saraiva, 2004., p. 45-62.

2 Esclarece José Carlos Barbosa Moreira ("A redação da Emenda Constitucional n 45 (Reforma da Justiça)". Revista Forense, Rio de Janeiro, v. 101, n.378, p. 39-46, mar./abr. 2005) que a "súmula da jurisprudência dominante", no singular, foi criada em 1963, pelo Supremo Tribunal Federal, a fim de compendiar as teses firmemente consagradas em suas decisōes, compondo-se de certa quantidade de proposiçōes que traduziam tais teses, razão pela qual a denominação oficial de "súmula" corresponderia ao conjunto, ao todo das teses compendiadas, não sendo adequado falar em "súmulas vinculantes" no plural. De todo modo, reconhece o jurista, a própria Emenda Constitucional $n^{\circ} 45 / 04$ assimilou o uso, antes informal, da expressão "súmulas vinculantes" no plural, de forma que não se fará tal diferenciação no presente trabalho. 
Tais fatos expressam a evolução dos mecanismos de jurisdição constitucional, no Brasil, para uma direção comum, de atribuição de força vinculante aos precedentes judiciais, representando, assim, uma aproximação do nosso sistema jurídico, tipicamente correspondente a um modelo de direito codificado-continental (civil law), ao sistema da common la $w^{3}$, no qual a idéia de vinculação a precedentes possui papel central.

A mencionada aproximação ao sistema da common law não constitui, todavia, uma abrupta ruptura com a tradição brasileira de direito estatutário. Ao contrário, ela resulta de um processo lento e paulatino. ${ }^{4}$

Para ilustrar esse processo paulatino de aproximação ao common law, mediante inserção e ampliação de mecanismos com efeitos vinculantes, basta lembrar que a Carta de 88 foi promulgada prevendo, como instrumentos do controle concentrado de constitucionalidade, a ação direta de inconstitucionalidade por ação, a ação direta de inconstitucionalidade por omissão e a ação direta interventiva (além da previsão genérica da argüição de descumprimento de preceito fundamental, então, sem contornos definidos).

Com a Emenda Constitucional $n^{\circ} 3 / 93$, introduziu-se, no sistema de controle concentrado, a ação declaratória de constitucionalidade, prevendo-se, expressamente, que as decisões nela proferidas produziriam eficácia contra todos e efeitos vinculantes com relação aos demais órgãos do Poder Judiciário e do Poder Executivo. Esta última disposição, por sua vez, levou à pacificação da discussão sobre a conferência de efeitos vinculantes à própria ação direta de inconstitucionalidade, sob a alegação de que esta última e aquela constituiriam a mesma ação "com o sinal trocado".

Em seguida, a Lei $n^{\circ} 9.868 / 99$ veio disciplinar o processo e o julgamento da ação direta de inconstitucionalidade e da ação declaratória de constitucionalidade,

3 De acordo com André Ramos Tavares (Reforma do Judiciário no Brasil pós-88: (des)estruturando a justiça: comentários completos à Emenda Constitucional n. 45/04. São Paulo: Ed. Saraiva, 2005, p. 108-109), o modelo codificado (civil law) se caracteriza pelo raciocínio abstrato e dedutivo, "que estabelece premissas e obtém conclusões por processos lógicos", a partir de normas gerais; ao passo que o modelo de precedente judicial (common law), fortemente centrado na decisão judicial (judge made law), atua por um raciocínio indutivo, pelo qual se busca nos julgados a fonte/norma de decisão dos casos subseqüentes.

4 Sobre não constituir a súmula vinculante uma ruptura em nossa história, cf. DINAMARCO, Cândido Rangel. "Súmulas Vinculantes". Revista Forense. Rio de Janeiro, v. 95, n. 347, p. 51-65, jul./set., 1999; SCAFF, Fernando Facury e MAUÉS, Antônio G. Moreira. "A trajetória brasileira em busca do efeito vinculante no controle de constitucionalidade". In WAMBIER, Teresa Arruda Alvim et al (org). Reforma do Judiciário: Primeiros ensaios críticos sobre a EC n. 45/2004. São Paulo: Ed. Revista dos Tribunais, 2005, p. 225-242; STRECK, Lênio Luiz. "Efeito Vinculante: desmi(s)tificações necessárias acerca dos projetos de reforma do Judiciário. Revista da Femargs $n$. 1. Disponível em: http://www.femargs.com.br/revista01_streck.html. Acesso em: 25 jun. 2005, p. 5. Sobre não constituir o efeito vinculante uma novidade no ordenamento jurídico brasileiro desde a Emenda Constitucional n ${ }^{\circ} 7 / 77$, cf. MENDES, Gilmar Ferreira. "O efeito vinculante das decisões do Supremo Tribunal Federal nos processos de controle abstrato de normas". Revista Jurídica Virtual, vol. 1, n. 4, agosto 1999. Disponível em: https://www.planalto.gov.br/ccivil_03/revista/Rev_04/efeito_vinculante.htm. Acesso em: 30 jun. 2005. 
corroborando os referidos efeitos vinculantes e reconhecendo aplicáveis tais efeitos, em ambas, inclusive no caso de interpretação conforme a Constituição e de declaração parcial de inconstitucionalidade sem redução de texto. Pouco depois, a Lei ${ }^{\circ}$ 9.882/99 regulamentou a argüição de descumprimento de preceito fundamental, novo instrumento com efeitos vinculantes.

Em sede de controle difuso, de igual modo, diversas leis ordinárias conferiram algum efeito impositivo às súmulas, a exemplo da Lei $n^{\circ} 9.756 / 98$, que atribuiu ao relator poderes para inadmitir ou improver recursos em confronto com as mesmas ou com jurisprudência dominante. ${ }^{5}$

Constata-se, assim, que a recém-criada súmula vinculante, fruto da Emenda Constitucional $n^{\circ} 45 / 04$, aparece como mais um capítulo de uma jurisdição constitucional que tem se dirigido à construção de um sistema de precedentes judiciais com caráter normativo, a despeito da adoção pelo Brasil do modelo de direito estatutário.

Nesse contexto, há que se indagar: quais são as modificações e os novos métodos que a inserção e ampliação dos efeitos vinculantes das decisões judiciais produzem (ou produzirão) na hermenêutica constitucional? A atribuição de tais efeitos aos precedentes interfere na forma de se pensar o direito ou na forma de argumentação e de fundamentação das decisões judiciais? Como se extraem legitimamente as regras vinculantes de um precedente? Como se identificam ou se diferenciam os precedentes, de modo a atrair ou a afastar a aplicação de decisões anteriores? Como se dá a superação/revogação de um precedente?

Esses assuntos, tão recorrentes nos países do sistema da common law, nos quais encontram vasta bibliografia, e indubitavelmente essenciais para o manejo dos precedentes, são, ainda, pouco tratados pela doutrina nacional, e sobre eles se debruçará neste trabalho.

Para tal, recorrer-se-á, no item 2, abaixo, a uma pesquisa do direito comparado, sobretudo do direito norte-americano, objetivando examinar a metodologia utilizada pela doutrina estrangeira na operação com precedentes. No item 3, procurar-se-á analisar como se dá o manejo de precedentes no direito brasileiro, tendo por ponto de referência a metodologia identificada no direito comparado. Por fim, no item 4, proceder-se-á à conclusão (inicial e aberta) acerca da consistência ou inconsistência da forma como já se vem trabalhando no Brasil com precedentes e sobre o impacto que a inserção ou ampliação dos efeitos vinculantes gera/gerará no funcionamento da jurisdição constitucional brasileira.

\section{Direito comparado}

Embora não se pretenda restringir o exame dos sistemas estrangeiros ao direito norte-americano, este representará, sem dúvida, o principal ponto de partida para a

5 Para um exame mais detido de tais leis ordinárias, cf. DINAMARCO, Cândido Rangel. $O p$. cit., p. 54-57. 
análise que se empreenderá abaixo, em especial, em razão da disponibilidade de farto material sobre o tema.

$\mathrm{Na}$ cultura jurídica norte-americana, o precedente constitui "a regra jurídica usada pela Corte de última instância no local em que o caso foi decidido, aplicada aos fatos relevantes que criaram a questão de mérito levada perante a Corte para decisão". Stare decisis, por sua vez, corresponde à "política que exige que as Cortes subordinadas à Corte de última instância que estabelece o precedente sigam aquele precedente e 'não mudem a questão decidida'. Este princípio, aplicando a doutrina do stare decisis para estabelecer precedente vinculante, veio para a cultura jurídica dos Estados Unidos da tradição do common law inglês" 6 .

De acordo com tal sistema, a parte, ao buscar um precedente aplicável à ação a ser julgada, precisa, primeiramente, identificar os fatos relevantes do caso concreto e, então, a questão legal que será decidida pela Corte em sua apreciação. Em seguida, a parte buscará um precedente que trate das mesmas questões de direito e no qual se constate, ainda, que a discussão sobre tais questões de direito se baseou essencialmente na mesma situação de fato relevante para a decisão do caso concreto sob exame, hipótese em que o precedente e o caso concreto a ser decidido serão considerados como casos análogos e, por conseguinte, em que estará justificada a aplicação do caso precedente como vinculante. ${ }^{7}$ Tal raciocínio analógico, por sua vez, apóia-se em alguns conceitos essenciais - os conceitos de holding, rationale e obiter dictum.

\subsection{Conceitos importantes para o manejo de precedentes. Holding. Rationale.} Obiter dictum

De acordo com a doutrina norte-americana, o holding constitui a norma, extraida do caso concreto, que vincula os tribunais inferiores ${ }^{8} ;$ o princípio jurídico que o tribunal estabeleceu para decidir; a regra necessária à solução do caso?.

6 COLE, Charles D. "Stare decisis na cultura jurídica dos Estados Unidos. O sistema de precedente vinculante do common law". Tradução: Maria Cristina Zucchi. In: RT n. 752, 1998, p 12.

7 COLE, Charles D. Op. cit., p. 15; SUMMERS, Robert S.. "Precedent in the United States (New York State)". In: MACCORMICK, D. Neil e SUMMERS, Robert S. (org.). Interpreting precedents: a comparative study. England: Dartmouth Publishing Company Limited e Ashgate Publishing Limited, 1997, p. 387; RE, Edward D. "Stare decisis". Tradução: Ellen Gracie Northfleet. Revista de Processo n. 73, jan./mar. 1994, p. 49.

8 SILVA, Celso de Albuquerque. Do Efeito Vinculante: sua Legitimação e Aplicação. Rio de janeiro: Lumen Juris, 2005, p. 182-183.

9 SUMMERS, Robert S.. "Precedent in the United States (New York State)". In: MACCORMICK, D. Neil e SUMMERS, Robert S. (org.). Interpreting precedents: a comparative study. Op. cit., p. 383: "The only part of the opinion which can be formally bidding (...) is the "holding' or 'holdings'. This is the portion of an opinion in which the court rules the issue (or issues) necessary to the decision". 
São dificuldades enfrentadas no trabalho com o conceito de holding: (a) a definição de quais são as formulações efetivamente imprescindiveis à decisão, questão de absoluta relevância, uma vez que justamente tais formulações corresponderão ao enunciado vinculante para as demais cortes; (b) a determinação dos limites do holding, se abrangentes ou não da fundamentação; (c) a existência de diversas teorias sobre seu conteúdo e a afirmação de diversos métodos para sua identificação; (d) a delimitação da regra vinculante de modo mais ou menos amplo ${ }^{10}$.

No que concerne à definição das proposições necessárias à decisão, esta dependerá de um exame dos fatos do caso concreto, da fundamentação e do que restou decidido. Em caso de dúvida, recorre-se ao seguinte método: destaca-se a formulação sobre cuja essencialidade se debate e procede-se à inversão de seu significado. Se disto decorrer uma alteração do resultado da decisão, será possível afirmar que tal formulação constitui preceito essencial à solução do caso. Do contrário, configurará mera consideração marginal não necessária à conclusão.

Quanto à dificuldade de determinação dos limites e do conteúdo do holding, vale recorrer à abordagem efetuada por Edward. D. RE para ilustrá-la. De acordo com este autor, a força vinculativa de um precedente se limitaria "ao princípio ou regra indispensável à solução das questões de fato e de direito efetivamente suscitadas e decididas", afirmativa que produz uma idéia restritiva do conteúdo do holding, próxima de sua limitação a uma "espécie" de dispositivo da decisão. Entretanto, em outra parte do mesmo trabalho, o autor afirma que apenas "os fundamentos da decisão merecem reconhecimento e acatamento com força vinculativa" "!

Robert S. Summers, por sua vez, observa que, quando o tribunal vinculante foca a maior parte da decisão na discussão acerca de um princípio de direito, a tendência da corte vinculada é de compreender o holding como uma aplicação de tal princípio. Se, ao contrário, a decisão se foca em certos fatos peculiares ao caso, é possível que se venha a compreender o holding de forma mais restritiva, limitado por tais fatos. Além disso, segundo o autor, a lógica (the reasoning of the precedent, nas palavras originais) pode gerar uma extensão do conteúdo do holding ${ }^{12}$. Tal variação de

10 Para a compreensão deste último aspecto, deve-se observar que, no direito norte-americano, a delimitação do conteúdo (mais ou menos amplo) do holding de um precedente envolve a participação das próprias cortes vinculadas. Isso ocorre porque, uma vez proferida a decisão vinculante, suas primeiras aplicações aos novos casos e, portanto, a extração de sua regra geral obrigatória será efetuada, inicialmente, pelas cortes inferiores, e, apenas posteriormente, submetida ao tribunal vinculante, em caso de recurso. Cf. SUMMERS. P.obert S.. "Precedent in the United States (New York State)". In: MACCORMICK, D. Neil e.SUMMERS, Robert S. (org.). Interpreting precedents: a comparative study. Op. cit., p. 384; MARSHALL, Geoffrey. "What is binding in a precedent". In: MACCORMICK, D. Neil e SUMMERS, Robert S. (org.). Interpreting precedents: a comparative study. Op. cit., p. 512; MALTZ, Earl. Op. cit.

11 RE, Edward D.. Op. cit., p. 49-50.

12 SUMMERS, Robert S.. "Precedent in the United States (New York State)". In: MACCORMICK, D. Neil e SUMMERS, Robert S. (org.). Interpreting precedents: a comparative study. Op. cit., p. 384. 
conteúdo se daria porque o holding de um caso se diferenciaria não apenas de sua fundamentação, mas igualmente de qualquer regra geral ou princípio extraível do holding. Enquanto o holding constituiria uma decisão específica sobre determinada questão, a regra ou o princípio constituiriam uma generalização formulada a partir do holding. Tal processo de formulação da regra ou do princípio, por sua vez, poderia gerar regras ou princípios com diversos graus de amplitude/generalidade, conforme: (a) a amplitude da questão em exame; (b) a lógica/fundamentação utilizada para decidi-la; (c) a possibilidade de (maior ou menor) generalização dos fatos pertinentes. ${ }^{13}$

Já Henry Paul Monaghan, após reconhecer a existência de discussão sobre o escopo dos efeitos vinculantes, especialmente no que concerne a abrangerem ou não a fundamentação da decisão judicial, assinala que a compreensão geral sobre a questão, nos Estados Unidos, se dá no sentido da não abrangência da motivação por tais efeitos. Entretanto, declarando divergir deste entendimento dominante, o autor defende a adoção da conceituação do holding como a regra explícita ou implicitamente tratada pelo juiz como um passo necessário a atingir a decisão, à luz das razóes por ele adotadas. ${ }^{14}$

No que respeita aos métodos para identificação do holding, registram-se: (a) o método fático-concreto; e (b) o método abstrato-normativo. Segundo o método fático-concreto, o holding corresponderia à regra extraída de um conjunto de fatos, que poderia ser expressa da seguinte forma: em qualquer situação em que estejam presentes os fatos A e B (relevantes), e presente ou não o fato $C$ (irrelavante), o resultado deverá ser $\mathrm{X}$. Um dos problemas de tal método é justamente a possibilidade de se entender cada fato em vários níveis de generalidade, pressupondo valorações que dependem da análise da fundamentação da decisão. ${ }^{15}$

13 SUMMERS, Robert S. "Precedent in the United States (New York State)". In: MACCORMICK, D. Neil e SUMMERS, Robert S. (org.). Interpreting precedents: a comparative study. Op. cit., p. 386-387.

14 MONAGHAN, Henry Paul. "Stare decisis and constitutional adjudication". In Columbia Law Review, vol, 88, 1988.

15 Um bom exemplo sobre a possibilidade de formulação das regras de precedentes de forma mais ou menos genérica é elencado por Celso de Albuquerque Silva (op. cit., p. 217), com base no caso Donoghue v Stevenson, em que o demandante sofrera danos em decorrência da presença de uma lesma morta na garrafa opaca de ginger beer que havia adquirido. Segundo o autor: "Limitando-nos apenas a estes dois fatos materiais: 1) o agente do dano e 2) o veículo do dano, eles podem ser considerados em si mesmos em vári’os níveis. Quanto ao agente do dano, o fato pode ser entendido como: lesmas mortas, ou quaisquer lesnuas, ou qualquer corpo físico estranho nocivo, ou qualquer elemento estranho físico ou não, ou quìquer elemento nocivo. Quanto ao veículo do dano, ele pode ser entendido como: garrafa de ginger beer opaca ou uma garrafa de bebida ou qualquer garrafa de bebida ou qualquer recipiente de mercadorias para consumo humano ou qualquer recipiente de qualquer bem móvel pa:a o uso humano, ou qualquer bem móvel ou qualquer coisa, incluindo terrenos e construções. Comı se pode ver desses simples exemplos, a restrição da regra criada judicialmente à conclusão decorrente da escolha dos fatos materiais no caso precedente não é hábil a assegurar a certeza jurídica perseguida pelo método". 
Já de acordo com o método abstrato-normativo, os tribunais, quando decidem o caso concreto, buscam estabelecer uma regra geral e abstrata que congregue uma classe completa de assuntos, transcendendo os limites do caso concreto e solucionando a lide de um modo mais amplo. Isso porque, se o que se faz agora vinculará o futuro, o tribunal decidirá com base no que é mais adequado para todos os casos que se encontrem dentro de uma apropriada categoria de assimilação. Nesta hipótese, os fundamentos justificantes, ou seja, as razões oferecidas pela Corte Constitucional, constituiriam a regra vinculante e determinariam a generalidade do holding do precedente. ${ }^{16}$

O importante, quanto a tais métodos, contudo, não é afirmar uma opção por um ou por outro, mas tentar identificar o que há, em cada um, de eloqüente para o trabalho com precedentes, em especial, para a fixação do conteúdo/limites do holding.

Nesse sentido, o método fático-concreto demonstra que a realidade fática é profundamente relevante para a determinação do teor vinculante do precedente, enquanto o método abstrato-normativo afirma a importância dos fundamentos deduzidos pela corte para tal fim; a partir de um exame crítico de ambos, pode-se concluir que: (a) é essencial que a decisão contenha um relatório preciso sobre os fatos, a fim de que se possam identificar aqueles que o tribunal vinculante considerou relevantes para proferi-la; (b) como os fatos estão sujeitos a valorações, não é possível extrair a regra abstraindo-se dos mesmos ou da compreensão do raciocínio empreendido pelo tribunal no que concerne a tais fatos e ao direito aplicável, razão pela qual, para a identificação da própria norma vinculante e sua aplicação a novos casos, é necessário passar pela fundamentação; (c) as regras extraídas a partir de fatos e do raciocínio empreendido em torno deles podem ser formuladas de modo mais ou menos genérico, ampliando-se ou não o escopo vinculante de um precedente, e, para a modulação de sua amplitude, torna-se novamente essencial o exame dos motivos determinantes da decisão.

Contata-se, assim, que a rationale, ou seja, a razão dada pela corte para adotar a norma que decide a lide ${ }^{17}$, é essencial para a definição da própria norma e para a delimitação de sua generalidade. Assim, não é possível determinar a regra vinculante sem recorrer à fundamentação do julgado. ${ }^{18}$

Tal conclusão, aliás, se alinha com as novas concepções da hermenêutica contemporânea, que afirmam que o processo de compreensão de um enunciado (ou de um julgado) é circular ${ }^{19}$, desenvolvendo-se através de um raciocínio que se movi-

16 SILVA, Celso de Albuquerque. Op. cit., p. 213-215.

17 SILVA, Celso de Albuquerque. Op. cit., p. 186.

18 MALTZ, Earl. Op. cit., salienta, inclusive, que a rationale assume especial importância na hipótese em que se pretende estender/ampliar a regra originalmente formulada em um precedente, ressalvando, contudo, que "however much weight such rationales are to be given in the judicial making process, only doctrine itself is formally protected by the concept of stare decisis".

19 Por processo circular de compreensão se tem a afirmação de que o processo de apreensão do conteúdo de uma norma se dá por meio de uma interação dialética entre o todo e a parte, de maneira 
menta da parte para o todo e de volta à parte, como forma de apreensão de seu conteúdo. Portanto, de um raciocínio que se movimenta da norma para o fato e de volta para a norma; da decisão para os fatos e para a fundamentação e de volta à decisão; do dispositivo para o relatório, para a motivação e de volta ao dispositivo. Tanto assim que, aos nos confrontarmos com uma decisão judicial, não nos atemos a ler apenas o seu dișpositivo, sendo necessário examinar seus motivos determinantes e a moldura fática do caso concreto para a plena apreensão de seu conteúdo.

Assim, pode-se concluir que há uma fundamentação mínima, que constitui a lógica da decisão e que orienta a conformação da própria regra a ser extraida do precedente. Há, igualmente, um background fático mínimo que delimita o holding, tanto assim que, se profundamente alterado, chegar-se-á, conforme o caso, à afirmação de inaplicabilidade do precedente, seja por se tratar de hipótese de distinguish $^{20}$ em razão de diferenças e peculiaridades fáticas, seja por sua efetiva não incidência à situação concreta porque muito diversa.

Reconhecido o papel relevante dos fundamentos na identificação da regra vinculante, por um lado, bem como a dificuldade de delimitar a amplitude de tal papel, por outro, torna-se interessante indagar, em termos metodológicos, se há alguma parte da motivação que poderia ser excluída dos efeitos vinculantes. Aqui entra a importância de um terceiro conceito, o de obiter dictum.

Constitui obiter dictum qualquer manifestação do Tribunal não necessária à solução do caso concreto, a exemplo de considerações marginais efetuadas pela corte, argumentos lançados por um dos membros do colegiado e não acolhidos ou apreciados pelo órgão, dissensos constantes de votos divergentes.

Tais manifestações não estão sujeitas à vinculação justamente porque a idéia do judge made law se centra na extração indutiva da regra vinculante a partir do caso concreto, e, se determinadas çonsiderações constantes de uma decisão não são necessárias à solução da demanda, as mesmas não derivam do caso concreto, mas

que a parte só se compreende mediante recurso ao todo, e este mediante retorno à parte. $\mathrm{O}$ significado de uma palavra só é adequadamente apreendido se considerada toda a frase, e o sentido da frase como um todo depende das palavras (CARMARGO, Margarida Maria Lacombe. Hermenêutica e argumentação: uma contribuição ao estudo do direito. Rio de Janeiro: Ed. Renovar, 2003, p. 53). Pelo mesmo raciocínio, a norma somente se enuncia em interação com o fato. Esta última idéia, por sua vez, conduz à noção de hermenêutica concretizadora. Quanto ao método da hermenêutica concretizadora, esclarece Daniel Sarmento (A Ponderação de Interesses na Constituição. Rio de Janeiro: Lumen Juris, $3^{a}$ ed., 2003, p. 133-135) que: "Tal método vislumbra a interpretação como um processo criativo, no qual o sentido da norma interpretada só pode ser obtido em face do problema concreto sobre o qual ela incide, pois, segundo Hesse, no existe interpretación desvinculada de los problemas concretos. A concretização da norma constitucional pressupõe sua pré-compreensão, que consiste na formulação de uma idéia antecipada sobre o seu conteúdo e limites, de modo abstrato. A partir da pré-compreensão, o intérprete aproxima-se do caso concreto, através de uma atuação tópica, orientada ao problema, mas limitada pela norma. Não se trata, porém, de um processo composto por duas fases sucessivas, onde primeiro se alcance o sentido da norma para só depois aplicá-la à hipótese concreta, e sim de um procedimento unitário, coeso e "circular'".

20 A noção de distinguish será tratada mais adiante, no item 2.2. 
de formulações hipotéticas, cujas especificidades, no plano abstrato, o Judiciário não teria como ponderar, não lhe competindo tal atribuição; cabendo-lhe apenas decidir lides. O obiter dictum poderá, contudo, ter alguma eficácia persuasiva ${ }^{21}$, conforme o caso.

Por fim, uma última palavra merece ser dita sobre a idéia de ratio decidendi. Esta expressão, assim como o próprio conceito de holding, não é unívoca, sendo utilizada, em algumas oportunidades, como sinônimo de holding ${ }^{22}$, e, em outras, como correspondente à fundamentação da decisão, à razão de decidir (mesmo porque, para alguns, o holding abrange a razão de decidir). Diante da dificuldade terminológica, evitar-se-á utilizar a expressão neste trabalho. Quando e se utilizada, contudo, dar-se-á preferência a atribuir-lhe o significado de fundamentação, pois este parece ser o sentido que vem sendo predominantemente reconhecido à mesma no Brasil, seja pela jurisprudência, seja pela doutrina ${ }^{23}$.

Esclarecidos tais pontos, em uma tentativa de síntese, pode-se afirmar que: (a) o holding, regra geral decorrente da decisão proferida no precedente e necessária à solução da demanda, é a parte da decisão à qual se atribuem efeitos vinculantes; (b) a identificação de tal regra depende de uma compreensão dos fatos considerados relevantes pelo tribunal vinculante, ou seja, dos material facts, e dos fundamentos, rationale, da decisão, razão pela qual alguns entendem que os próprios motivos necessários à solução do caso integram o holding e, portanto, também vinculam; (c) em verdade, nota-se que a fragmentação radical das partes de um julgado é artificial e não possibilita uma abordagem adequada do problema do conteúdo vinculante, sendo possível afirmar que há uma interação entre os elementos da decisão, resultando de tal interação, em especial com a fundamentação, a extração da regra vinculante; (d) reconhecida a importância da rationale para identificação/conformação do holding, debate-se acerca de seus efeitos vinculantes, bem como da generalidade com que se virá a formular a regra emergente do precedente, a partir de sua compreensão; (e) obiter dictum ou considerações marginais, não necessárias à decisão, não possuem eficácia vinculante, podendo, contudo, possuir eficácia persuasiva, conforme o caso.

\subsection{Distinguish}

Outra noção importante e relacionada aos conceitos explicitados acima é o conceito de distinguish(ing). O distinguish constitui uma exceção à regra geral.

21 SUMMERS, Robert S.. "Precedent in the United States (New York State)". In: MACCORMICK. D. Neil e SUMMERS, Robert S. (org.). Interpreting precedents: a comparative study. Op. cit., p. 385.

22 Cf. SILVA, Celso de Albuquerque. Op. cit., p. 182-184.

23 Cf. Rcl $n^{\circ}$ 1.987-0-DF, STF, Pleno, Min. Rel. Maurício Correa, DJ de 21-05-04, p. 33; GRECO, Leonardo. "Novas súmulas do STF e alguns reflexos sobre o mandado de segurança". Revista Dialética de Direito Processual, São Paulo, n. 10, p. 44-54, jan. 2004. 
Corresponde à não aplicação de um precedente, a despeito de o caso concreto incluir-se no âmbito normativo de seu holding, basicamente ao argumento de que os fatos relevantes (material facts) ou a lógica da decisão, de sua fundamentação (substantive rationale), não são aplicáveis aos fatos específicos do caso a ser decidido, por suas peculiaridades.

Constituem hipóteses de distinguish, exemplificativamente ${ }^{24}$ : (a) o conflito com normas derivadas de outros precedentes vinculantes, ensejando limitação da aplicação do precedente anterior; (b) a existência de regra vinculante baseada em claro $e$ inadvertido erro, ensejando limitação da aplicação do precedente anterior (desde que, segundo Celso de Albuquerque Silva, para tal baste a mera redução do âmbito de incidência do precedente e que tal erro seja objetivamente aferível, a exemplo de uma situação de fato considerada relevante pela própria corte superior, mas a respeito da qual esta deixou de ponderar $)^{25}$; (c) o reconhecimento de situações que a corte vinculante claramente não queria abranger quando fixou a regra, igualmente ensejando limitação da aplicação do precedente anterior; (d) a constatação da existência. no caso a ser decidido, de peculiaridades fáticas que justificam um tratamento diferenciado do problema.

As hipóteses de distinguish indicadas acima reafirmam a importância do confronto das especificidades da causa que ensejou a regra vinculante com as especificidades fáticas da demanda concreta em exame, bem como da fundamentação deduzida pelo tribunal vinculante, para a decisão sobre identificação ou distinção entre casos, para fins de aplicação ou não da regra vinculante anteriormente formulada.

Demonstram, ainda, que o raciocínio empreendido com base nos precedentes, embora marcadamente analógico, não difere muito daquele utilizado na interpretação de normas em geral, especialmente no que respeita à análise sistemática, teleológica e ponderativa da norma vinculante na solução de antinomias. Fica claro, ademais, pelo acima exposto e pelo que se deduzirá adiante, que a operação com precedentes compatibiliza-se perfeitamente com a hermenêutica contemporânea, com as idéias de $t o p o i^{26}$,

24 SILVA, Celso de Albuquerque. Op. cit., p. 247-258.

25 SILVA, Celso de Albuquerque. Op. cit., p. 250-252.

26 "Na tópica, o pensamento jurídico é essencialmente problemático. Enquanto no modo de pensar sistemático parte-se do sistema para dele deduzir a solução para o caso, na tópica o ponto de partida é o problema. Inverte-se, portanto, a perspectiva de aplicação do direito, cuja ênfase passa a recair na indução e não mais na dedução. A partir do caso concreto o operador do direito deve buscar a solução mais justa, através de um procedimento circular, por intermédio do qual são testados diversos topoi (pontos de vista), para verificar qual deles acena com a melhor resposta para o problema a ser enfrentado. (...). O conceito de topoi é fundamental para a compreensão da tópica. Os topoi configuram lugares comuns na argumentação discursiva, que não vinculam o juiz, mas apenas apresentam-lhe alternativas possiveis para a solução de determinado problema. (...). A decisão, na tópica, resulta de um confronto dialético entre os diversos topoi pertinentes ao caso, devendo prevalecer aquele que contribuir para a construção da solução mais justa" (SARMENTO, Daniel. A Ponderação de Interesses na Constituição. Rio de Janeiro: Lumen Juris, $3^{\text {a }}$ ed., 2003, p. 128-129). "O método do direito é, portanto, um método tópico-hermenêutico. Cada situação deve ser compreendida em função do problema que apresenta e da tradição histórica na qual se insere. 
$\operatorname{argumentação~}^{27}$, concretização $^{28}$, sistema aberto ${ }^{29}$ e compreensão circular ${ }^{30}$.

Por outro lado, se a operação com precedentes vinculantes suscita questões hermenêuticas semelhantes àquelas relacionadas à interpretação das normas em geral, e tais efeitos vinculantes foram criados, em nosso direito, justamente a fim de reduzir as controvérsias em torno da interpretação e aplicação de normas jurídicas, há em tal constatação um certo paradoxo. As súmulas, criadas para garantir maior previsibilidade e segurança, como as normas em geral, estarão sujeitas igualmente a interpretação e a controvérsias. Assim, em lugar de reduzirem incertezas, podem passar a fontes geradoras de ambigüidades.

\subsection{Overruling e Overriding}

Por fim, são importantes as noções de overruling e overriding, correspondendo a primeira à revogação total de um precedente e a segunda a sua revogação parcial. O trabalho com tais idéias e com a decisão sobre a revogação ou não de precedentes se centra, no cotejo do acerto, desacerto, inconveniência ou obsolescência do precedente que se pretende revogar, portanto, de sua (in)congruência social e/ou de sua (in)consistência sistêmica ${ }^{31}$, justamente com os dois valores principais que justificam a adoção de precedentes com efeitos vinculantes: (a) segurança jurídica/proteção da confiança dos cidadãos; e (b) isonomia. ${ }^{32}$

Isso porque, estabelecido um precedente, os jurisdicionados tomam diversas decisões (por exemplo, econômicas), com base no entendimento nele expressado,

Mas o seu instrumental é argumentativo" (CARMARGO, Margarida Maria Lacombe. Hermenêutica e Argumentação: Uma Contribuição ao Estudo do Direito. 3. ed. Rio de Janeiro: Ed. Renovar, 2003, p. 22).

27 Argumentação é "a técnica que visa ao acordo sobre a escolha do significado que pareça mais adequado às partes discursivas" (CARMARGO, Margarida Maria Lacombe. Op. cit., p. 21-22). Segundo Daniel Sarmento (op. cit., p. 125): "no campo das relaçōes humanas, as discussð̃es dão-se em torno de argumentos, prevalecendo aquele que tiver maiores condições de convencer os interlocutores. Não há verdades apodíticas, mas escolhas razoáveis, que são aquelas que podem ser racionalmente justificadas".

28 De acordo com CARMARGO, Margarida Maria Lacombe. Op. cit., p. 44-45: "Na realidade, não se trata de subsumir um fato a uma idéia geral, porque, a nosso ver, a idéia da norma já nasce, para o intérprete, concreta; e concreta, justamente, porque adstrita ao fato que se compreende. (...) Essas considerações sustentam nossa hipótese de admitir o direito como concretização. A norma só ganha significado quando assume uma posição concreta, ou melhor, quando se revela realmente". 29 Segundo CANARIS, Claus-Wilhelm. Pensamento sistemático e conceito de sistema na ciência do direito. Lisboa: Fundação Calouste Gulbenkian, 2002, p. 281: o sistema é aberto tanto no seu aspecto científico, quanto no que concerne a seu aspecto objetivo. "A propósito do primeiro, a abertura significa a incompleitude do conhecimento científico, e a propósito do último, a mutabilidade dos valores jurídicos fundamentais".

30 Conceito já esclarecido acima (nota de rodapé $n^{\circ} 19$ ).

31 ALEXANDER, Larry. "Constrained by Precedent". In: University of Southern California Law Review, 1989.

32 Idem ibidem. 
de modo que sua alteração pode gerar sérias repercussões e um grave sentimento de incerteza. Além disso, a modificação de um entendimento implica em conferir tratamento diferenciado e, por conseguinte, desigual, àqueles que ajuizarão suas demandas após tal evento, efeitos que o sistema de precedentes vinculantes não pode evitar, mas que. em certa medida, objetiva mitigar. Por tal razão, a superação de precedentes sempre levará em conta tais valores de segurança e isonomia, ponderando-os com aqueles que militam em favor da mudança.

Nessa linha, elencam-se, exemplificativamente, como razões que autorizam ou justificam o overruling ${ }^{33}$ : (a) a desfiguração do precedente por distinções arbitrárias, efetuadas pelos juízes vinculados como uma forma de insubordinação tácita/velada contra a aplicação de um precedente (normalmente por perceberem o precedente como injusto ou incorreto); (b) precedentes inexeqüíveis na prática porque a regra não é capaz de oferecer uma orientação segura, a exemplo do que ocorre caso se utilizem na formulação da regra vinculante conceitos vagos sem o estabelecimento de pautas suficientes à sua determinação; (c) a compreensão atual do precedente como injusto/incorreto, inclusive em virtude de alterações culturais, políticas, sociais, econômicas ou tecnológicas ${ }^{34}$; (d) a superveniência de lei em sentido contrário; ${ }^{35}$ (e) uma alteração da "filosofia jurídica" da corte vinculante ${ }^{36}$.

Nas duas primeiras hipóteses indicadas acima, seriam dificilmente invocáveis razões de segurança jurídica ou de isonomia contra a superação do precedente. Ao contrário, possivelmente tais valores se veriam mais resguardados pela revogação do antigo precedente inconsistente e pela formulação de um novo precedente.

No terceiro e no quinto casos especialmente, tais razões de proteção à segurança e à isonomia, se efetivamente presentes, deveriam ser ponderadas ${ }^{37}$ com aquelas outras razões que militam em prol da modificação do precedente, decidindo-se, caso a caso, à luz dos resultados da ponderação, sobre proceder ou não a sua superação.

33 SILVA, Celso de Albuquerque. Op. cir., p. 262-284.

34 SUMMERS, Robert S.. "Precedent in the United States (New York State)". In: MACCORMICK, D. Neil e SUMMERS, Robert S. (org.). Interpreting precedents: a comparative study. Op. cit., p. 374.

35 Cf. SILVA, Celso de Albuquerque. Op. cit, p. 266-284; SUMMERS, Robert S. "Precedent in the United States (New York State)". In: MACCORMICK, D. Neil e SUMMERS, Robert S. (org.). Interpreting precedents: a comparative study. Op. cit., p. 396; SUMMERS, Robert S.. "Departures from precedents". In: MACCORMICK, D. Neil e SUMMERS, Robert S. (org.). Interpreting precedents: a comparative study. Op. cit., p. 525.

36 Cf. COLE, Charles D.. Op. cit., p. 18.

37 A ponderação de valores (de bens, de interesses) constitui mecanismo de solução de antinomias, pelo qual se busca otimizar a eficácia dos bens em conflito, estabelecendo uma relação de primazia entre cada um, à luz do caso concreto, de forma a possibilitar o "convívio entre valores e princípios antagônicos e, assim, preservando a base material pluralista sobre a qual repousa a ordem constitucional" (SARMENTO, Daniel. Op. cit., p. 139-140); Cf. BARROSO, Luís Roberto. Interpretação e aplicação da Constituição. 5. ed. São Paulo: Saraiva, 2003, p. 218-246; Á VILA. Humberto. Teoria dos princípios: da definição à aplicação dos princípios jurídicos. 3. ed. São Paulo: Malheiros, 2004, p. 95-96. 
Nas hipóteses, contudo, em que razões de segurança jurídica e/ou de isonomia desaconselham a revogação do precedente, há possibilidade de recurso a formas intermediárias de decisão, como técnica que possibilita otimizar a eficácia de todos os valores em tensão e impor sacrifício mínimo a cada um.

Uma forma de decisão intermediária, no sentido mencionado acima, é o prospective overruling, pela qual, a despeito da aplicação do precedente antigo ao caso concreto que ensejou sua superação, acrescenta-se à decisão a informação de que, para os eventos ocorridos a partir de então ou de determinada data fixada na própria decisão, o precedente antigo não mais será aplicado, considerando-se superado ${ }^{38}$.

Outra modalidade de decisão intermediária consiste na técnica do signaling, em que o tribunal vinculante, ao apreciar determinado caso concreto, aplica-lhe o precedente antigo, mas informa, sinaliza à comunidade jurídica a intenção de alterá-lo, o que afasta, a partir do aviso, a justificada confiança em sua aplicação, abrindo caminho para sua superação.

Nota-se, assim, que a idéia de vinculação a precedentes somente implicará na petrificação do direito em caso de um equivocado manejo do instituto, porque há diversos instrumentos que possibilitam o desenvolvimento de distinções e a revogação de precedentes, ferramentas que podem, inclusive, impulsionar um trabalho mais criativo da jurisprudência com base em fatos e na argumentação principiológica desenvolvida a partir dos mesmos.$^{39}$

\subsection{Outros aspectos relevantes para o trabalho com precedentes. Relatório e} fundamentação das decisões. Educação dos advogados e dos magistrados.

\section{Tecnologias}

Diante do acima exposto, pode-se constatar a importância para o trabalho com precedentes: (a) da produção de um relatório detalhado sobre os fatos relevantes para a decisão; (b) de uma ampla e transparente fundamentação dos julgados, estes dois primeiros, requisitos essenciais à adequada extração da regra vinculante; (c) da divulgação adequada e célere das decisões judiciais; (d) de sua sistematização/organização por assuntos, a fim de facilitar a pesquisa; (e) do desenvolvimento de técnicas de argumentação e do treinamento dos profissionais no raciocínio analógico acima referido.

38 Vale ressalvar a existência de diversas discussões em torno da idéia de prospective overruling. que vão desde a controvérsia sobre a aplicação do precedente antigo ao caso concreto que possibilitou sua própria superação, até questionamentos sobre os efeitos vinculantes da decisão que afirma a superação do precedente a partir de determinada data, sob o fundamento de não se tratar tal manifestação de aspecto necessário à formulação da decisão no caso concreto e, por conseguinte, de não compor o holding. Sobre o assunto, cf. SILVA, Celso de Albuquerque. Op. cit., p. 284-295. 39 Como salienta COLE, Charles D. Op. cit., p. 21: "Precedente vinculante nos Estados Unidos não significa, porém, que o precedente de um caso esteja escrito em pedra”. No mesmo sentido, MACCORMICK, D. Neil e SUMMERS, Robert S. "Further General Reflections and Conclusions". In: MACCORMICK, D. Neil e SUMMERS, Robert S. (org.). Interpreting precedents: a comparative study. Op. cit., p. 532. 
Tais elementos já bastam para identificar alguns desafios que se enfrentará no Brasil e demonstram que a introdução ou fortalecimento da idéia de precedente vinculante em um sistema jurídico afeta a prática do direito como um todo, o método de ensino jurídico e as tecnologias necessárias a conferir suporte a tal idéia.

Assim, torna-se necessário treinar os estudantes na análise de casos, o que, segundo Charles D. Cole, demandaria um formato participativo de aulas, sendo inadequado o modelo meramente expositivo. Torna-se necessário, ainda, preparar os advogados e magistrados para operar com tais precedentes, e criar, para os últimos, inclusive, condições adequadas e mesmo uma cultura de expor, de forma mais detalhada e ampla, os fatos e fundamentos de suas decisões. Demanda-se, por fim, um sistema de publicação e de pesquisa de julgados rápido e organizado. ${ }^{40}$

Em uma análise das diferenças entre os sistemas de common law e de civil law no que concerne à metodologia de trabalho com precedentes, Neil MacCormick e Robert S. Summers identificaram, dentre outros, os seguintes pontos de distinção quanto ao manejo de precedentes em países do civil law ${ }^{41}$ : (a) publicação das decisões, com escasso detalhamento dos fatos e da fundamentação; (b) ausência de análise detalhada do precedente a ser aplicado e do caso concreto à luz dos material facts; (c) não diferenciação entre ratio decidendi e obiter dictum; (d) não desenvolvimento de uma metodologia de distinção entre precedentes já fixados e novos casos trazidos a julgamento; (e) insuficiência de um único precedente para gerar vinculação, sendo necessária a line of precedentes; (f) superação ou distinção de precedentes sem sequer mencionar o fato ou fundamentá-lo. ${ }^{42}$

Fixados tais pontos e sem compromisso de uma abordagem de todos eles, passa-se, a seguir, a analisar como se vem lidando com a idéia de vinculação a precedentes, no direito brasileiro, a partir de três aspectos: (a) a metodologia empregada para identificação da regra vinculante produzida pelo precedente; (b) a operação com a idéia de distinguishing; (c) o trabalho com a noção de overruling.

\section{O manejo de precedentes no direito brasileiro}

\subsection{Regra vinculante}

No sistema brasileiro, a idéia de vinculação a precedentes suscita questionamentos sobre sua compatibilidade com o princípio da separação dos poderes, uma

40 COLE, Charles D. Op. cit., p. 20-21.

41 MACCORMICK, D. Neil e SUMMERS, Robert S. "Further General Reflections and Conclusions”. In: MACCORMICK, D. Neil e SUMMERS, Robert S. (org.). Interpreting precedents: a comparative study. Op. cit., p. 536-539 e p. 546-549.

42 É importante observar, contudo, que a obra em questāo se propôs a examinar a forma como os países do civil law lidam com precedentes judiciais em geral, e não estritamente com precedentes vinculantes, a fim de confrontá-la com o modo de operar precedentes dos países do common law. 
vez que, argumenta-se, importaria no reconhecimento de atribuição normativa à corte vinculante, portanto, ao Judiciário.

Sem adentrar aqui na discussão sobre a compatibilidade (ou não) da vinculação a precedentes, ou especificamente das súmulas vinculantes, com o princípio da separação dos poderes, e pressupondo-se mesmo tal compatibilidade, uma coisa é certa: o exercício do poder vinculante pelo Supremo Tribunal Federal, fora das hipóteses em que constitucionalmente autorizado, de forma explícita ou implícita, a tal, importaria violação à Constituição.

Assim, as súmulas vinculantes editadas pelo Supremo Tribunal Federal deverão, necessariamente, nos termos da Emenda 45/04, decorrer de suas reiteradas decisões sobre matéria constitucional. Deverão, ainda, versar sobre validade, interpretação ou eficácia de normas determinadas, acerca das quais haja controvérsia atual que acarrete grave insegurança jurídica e relevante multiplicação de processos. ${ }^{43}$

Em síntese, os julgados que derem origem à súmula terão efetivamente de ter examinado e decidido a questão jurídica correspondente à proposição vinculante, sob pena de não decorrer a súmula de reiteradas decisões sobre a matéria, representando, por conseguinte, um exercício inconstitucional e ilegítimo de poder vinculante.

Sobre o tema já manifestara Leonardo Greco que: "a súmula, cujo enunciado não corresponder rigorosamente às rationes decidendi dos precedentes de que decorreu a sua formulação, constitui um verdadeiro abuso de poder do tribunal que a edita e não pode ser imposta como critério de uniformização de jurisprudência (...), sob pena de se dar força normativa a uma simples decisão administrativa de um tribunal superior" 44 .

Nota-se, deste modo, que as idéias de holding (regra necessária à decisão do caso), obiter dictum (considerações marginais desnecessárias à solução do caso), rationale (lógica da decisão) e material facts (fatos relevantes para a solução do caso), bem como as discussões acima sobre limites e conteúdo do holding e o grau de generalidade na formulação da norma vinculante, constituem ferramentas impor-

43 É a seguinte a redação da Emenda Constitucional n ${ }^{\circ}$ 45/04: “. O Supremo Tribunal Federal poderá, de ofício ou por provocação, mediante decisão de dois terços dos seus membros, após reiteradas decisões sobre matéria constitucional, aprovar súmula que, a partir de sua publicação na imprensa oficial, terá efeito vinculante em relação aos demais órgãos do Poder Judiciário e à administração pública direta e indireta, nas esferas federal, estadual e municipal, bem como proceder à sua revisão ou cancelamento, na forma estabelecida em lei. $\S 1^{\circ} \mathrm{A}$ súmula terá por objetivo a validade, a interpretação e a eficácia de normas determinadas, acerca das quais haja controvérsia atual entre órgãos judiciários ou entre esses e a administração pública que acarrete grave insegurança jurídica e relevante multiplicação de processos sobre questão idêntica. $\$ 2^{\circ}$ Sem prejuízo do que vier a ser estabelecido em lei, a aprovação, revisão ou cancelamento de súmula poderá ser provocada por aqueles que podem propor a ação direta de inconstitucionalidade. $\S 3^{\circ}$ Do ato administrativo ou decisão judicial que contrariar a súmula aplicável ou que indevidamente a aplicar, caberá reclamação ao Supremo Tribunal Federal que, julgando-a procedente, anulará o ato administrativo ou cassará a decisão judicial reclamada, e determinará que outra seja proferida com ou sem a aplicação da súmula, conforme o caso."

44 GRECO, Leonardo. Op. cit., p. 3. 
tantes para um exame crítico a respeito do exercício do poder de sumular pelo Supremo Tribunal Federal e, por conseguinte, para seu controle. Obviamente, tais idéias, oriundas de ordenamentos diversos, não trazem respostas e soluções absolutas, mesmo porque, como visto acima, não encontram respostas unívocas nem mesmo em seu sistema original. Auxiliam, contudo, o raciocínio na matéria, tão embrionário ainda no sistema brasileiro.

Neste passo, torna-se interessante apurar a compatibilidade entre algumas súmulas editadas pelo STF (anteriores à Emenda 45/04) e os acórdãos que thes serviram de paradigma.

Em trabalho que teve por objeto justamente a idéia acima, Leonardo Greco se propôs a examinar as Súmulas $n^{\circ} 622,625$ e 626 editadas pelo Supremo Tribunal Federal, valendo efetuar aqui um resumo a respeito de suas conclusões.

Em breve síntese, concluiu o Professor, no que concerne à Súmula $622^{45}$, que esta: (a) já nasceu obsoleta, contrariando tendência oposta da jurisprudência do Superior Tribunal de Justiça e refletindo interpretação anacrônica do art. 19 da Lei do Mandado de Segurança, assentada pelo Supremo Tribunal nos primórdios do instituto, quando ainda se duvidava que fosse uma ação, fato que ensejou a inaplicação ao mesmo de diversas disposições do Código de Processo Civil (dentre as quais, inclusive, os honorários de sucumbência e os embargos infringentes); (b) não indica como paradigma um único acórdão proferido há menos de quatro anos, circunstância que levaria a crer, erroneamente, que alguns dos Ministros mais novos não se teriam pronunciado sobre a questão, quando consulta ao portal do Tribunal na internet aponta para uma decisão no mesmo sentido daquela correspondente à da súmula, proferida em 29-05-03, demonstrando, portanto, sua falha remissiva; (c) versa sobre aplicação de lei federal, a respeito da qual a última palavra compete ao Superior Tribunal de Justiça, não ao Supremo Tribunal Federal.

Quanto à Súmula $625^{46}$, STF, salientou Greco que: (a) baseou-se ela em quatro julgados dos quais três foram proferidos há mais de doze anos; (b) no julgado menos antigo no qual se baseou, mesmo assim proferido há mais de quatro anos, $o$ ponto que é objeto da súmula sequer chegou a ser apreciado, uma vez que o recurso extraordinário não foi conhecido; (c) no terceiro julgado apontado como paradigma, a doutrina adotada pela súmula foi abordada como mera consideração marginal (obiter dictum), não constituindo objeto da ratio decidendi; (d) nos dois primeiros acórdãos citados como paradigma, o voto mais significativo não aduziu qualquer argumentação de nível constitucional: (e) o teor exato do enunciado da súmula não se encontra, de forma expressa, em nenhum dos acórdãos referidos; ao contrário, os quatro julgados afirmavam que direito líquido e certo corresponde à exigência de comprovação documental dos pressupostos fáticos do direito do impetrante; nenhum dos julgados discutia sobre a possibilidade de concessão de mandado de segurança

45 "Não cabe agravo regimental contra decisão do relator que concede ou indefere liminar em mandado de segurança".

46 "Controvérsia sobre matéria de direito não impede a concessão de mandado de segurança". 
em caso de controvérsia sobre matéria de direito, tal qual versado pela súmula, concluindo o autor que: "a súmula diz mais do que deveria dizer, do ponto de vista estritamente jurídico, mas nada do que tenha dito qualquer dos acórdãos referidos".

Por fim, no que concerne à Súmula 626, $\mathrm{STF}^{47}$, abstraindo-se de seu mérito, do qual discorda por razões alheias às questões ora tratadas, observou que: (a) todos os acórdãos apontados como referência foram proferidos há mais de cinco anos; (b) o voto de desempate proferido no leading case foi acompanhado por outros cinco Ministros, dos quais quatro já deixaram o Tribunal; (c) dos seis julgados paradigma, dois são imprestáveis para sustentar o verbete aprovado, dois se referem a suspensão de execução de sentença em mandado de segurança, enquanto o enunciado da súmula se refere a suspensão de liminar, e um terceiro se refere à questão apenas a título de obiter dictum; (d) a súmula não corresponde a interpretação da Constituição, mas de norma infraconstitucional.

Em conclusão, afirmou Greco:

"A sucinta análise dá uma pequena amostra, resultante do exame de apenas $3 \%$, das inúmeras deficiências na elaboração das novas súmulas pelo Supremo Tribunal Federal; assinala a esdrúxula autonomia que os seus enunciados adotam em relação aos precedentes em que se basearam, tornando-se verdadeiras normas genéricas e abstratas semelhantes às emanadas do Poder Legislativo; evidenciam que o mecanismo continua a ser manipulado de forma absolutamente autoritária, dissociada de qualquer critério que valorize a função da jurisprudência como instrumento de equilíbrio na evolução gradual da ordem jurídica; mostram que é preciso distinguir, quanto à eficácia, as súmulas que decorrem do exercício da missão do STF como guardião da Constituição, daquelas em que o Tribunal decide como qualquer outro órgão jurisdicional, (...); revelam que, em muitos casos, ao contrário de pacificarem divergências existentes, as novas súmulas vão estimulá-las, suscitando jurisprudência sobre a jurisprudência; e, o que parece mais grave e preocupante, indicam a falta de legitimidade de imposição de doutrinas fundadas em julgamentos proferidos por composição totalmente ultrapassada do próprio Tribunal, a que os novos ministros não deveriam estar dando o seu endosso sem revelarem publicamente, em votos proferidos em causas judiciais, porque aderem às orientações cuja cristalização referendam e que, na verdade, estão sendo impostas à sociedade com base em decisões pretéritas mal costuradas, em cuja elaboração não tiveram eles qualquer influência" 48 .

47 “A suspensão liminar em mandado de segurança, salvo determinação em contrário da decisão que a deferir, vigorará até o trânsito em julgado da decisão definitiva de concessão da segurança ou, havendo recurso, até a sua manutenção pìlo Supremo Tribunal Federal, desde que o objeto da liminar deferida coincida, total ou parcialmente, com o da impetração".

48 GRECO, Leonardo. Op. cit., p. 9. 
Assim, verificam-se diversas inconsistências no trabalho do STF, no que diz respeito à elaboração de súmulas anteriormente à Emenda 45/04. Curiosamente, algumas de tais inconsistências foram retratadas por Neil MacCormick e Robert S. Summers no estudo comparativo já mencionado no item $2.4 .^{49}$ como recorrentes na jurisprudência de países que adotam o direito estatutário, o que indica constituírem, de algum modo, um traço comum ligado à própria cultura dos países do civil law no manejo de precedentes. ${ }^{50}$

De todo modo, é importante observar que as súmulas antes examinadas foram editadas como proposições que sintetizam entendimentos da jurisprudência dominante do STF com finalidade eminentemente orientadora e eficácia persuasiva, sendo anteriores à Emenda $n^{\circ} 45 / 04$, e que tal situação guarda marcantes diferenças e naturalmente enseja ponderações diversas daquelas suscitadas pela emissão de súmulas com caráter vinculante. ${ }^{51}$

Já no que se refere à extração de regra vinculante no âmbito da jurisdição constitucional concentrada, a discussão é um pouco diversa. Isso porque, nesta sede, a definição da regra vinculante é efetuada, inicialmente, pelo juiz vinculado, quando invocado perante ele o precedente do STF, sujeitando-se tal atividade do magistrado à correção pela Corte Constitucional (ao passo que, no caso da súmula, como já demonstrado, o próprio Supremo Tribunal fixa, de início, a proposição que entende emergir de suas decisões, através da edição de um enunciado-síntese).

No controle concentrado, as discussões se centram, hoje, no alcance objetivo dos efeitos vinculantes, debatendo-se, basicamente, se estes se restringem ao dispositivo da decisão ou se se estendem a seus motivos determinantes, fenômeno este designado eficácia transcendente da fundamentação ${ }^{52}$

Embora inaugurada em momento um pouco anterior, essa discussão foi enfrentada pela primeira vez de forma mais explícita no ano de 2003, através da Reclamação $\mathrm{n}^{\circ}$ 1.987-0-DF, que, apesar de não ter sido o primeiro caso sobre o assunto, é considerado o leading case a seu respeito, por ter ensejado um amplo e até acalorado

49 MACCORMICK, D. Neil e SUMMERS, Robert S. "Further General Reflections and Conclusions". In: MACCORMICK, D. Neil e SUMMERS, Robert S. (org.). Interpreting precedents: a comparative study. Op. cit., p. 536-539 e p. 546-549.

so Entretanto, vale reiterar aqui a ressalva já efetuada anteriormente, no sentido de que o estudo comparativo em questão procedeu ao exame da forma como paises do civil law operam com precedentes de um modo geral, e não exclusivamente com precedentes vinculantes.

51 Há, no entanto, autores que entendem que mesmo antes da Emenda $n^{\circ} 45 / 04$ as súmulas já eram dotadas de alguma eficácia impositiva. Cf. DINAMARCO, Cândido Rangel. Op. cit., p. 51-65; STRECK, Lênio Luiz. "Efeito vinculante: desmi(s)tificações necessárias acerca dos projetos de reforma do Judiciário". Op. cit..

52 Vale observar que o nosso controle concentrado de constitucionalidade, diversamente de nosso controle difuso de matriz norte-americana, foi inspirado pelo modelo europeu, e que a idéia de eficácia transcendente da fundamentação no Brasil inspira-se no direito constitucional alemão. Entretanto, tal fato não infirma a utilidade dos conceitos já apresentados, mesmo porque a discussão sobre a eficácia transcendente encontra correspondência com as discussões travadas no âmbito do common law sobre o conteúdo e limite do holding. 
debate sobre o tema entre os Ministros que participaram do julgamento. Em sua ementa, restou consignado que:

"Hipótese a justificar a transcendência sobre a parte dispositiva dos motivos que embasaram a decisão e dos princípios por ela consagrados, uma vez que os fundamentos resultantes da interpretação da Constituição devem ser observados por todos os tribunais e autoridades, contexto que contribui para a preservação e desenvolvimento da ordem constitucional. ${ }^{53}$

Neste caso, examinava-se a seguinte situação. A Instrução Normativa $n^{\circ} 11 / 97$ do Tribunal Superior do Trabalho equiparara as situações de não inclusão do débito no orçamento e a de pagamento inidôneo (a menor ou realizado fora do prazo) de precatório à hipótese de preterição de direito de preferência, em que a Constituição admite o seqüestro de verbas públicas necessárias à quitação da dívida. Tal equiparação efetuada pela Justiça do Trabalho tinha por objetivo possibilitar o sequestro de verbas públicas para o pagamento de dívidas trabalhistas também nos dois primeiros casos, para os quais não havia previsão Constitucional de tal medida.

Através da ADIN $n^{\circ} 1.662$, proposta pelo Governador do Estado de São Paulo em 1997, foi requerida e declarada pelo STF a inconstitucionalidade da mencionada Instrução. No ano de 2000, o Congresso Nacional promulgou a Emenda Constitucional $\mathrm{n}^{\circ} 30$, alterando algumas regras concernentes a precatórios, nada modificando, porém, quanto ao ponto em questão. Entretanto, a pretexto de embasar-se, então, na nova redação da Carta conferida pela mencionada Emenda $n^{\circ} 30$, a Juíza Presidente do Tribunal Regional do Trabalho da $10^{a}$ Região determinou o seqüestro de determinada importância para pagamento de um precatório em hipótese diversa daquela de preterição do direito de precedência, a qual, conforme exegese fixada pela Corte Constitucional na $\mathrm{ADIN} \mathrm{n}^{\circ} 1.662$, era a única em que a Constituição autorizaria o seqüestro de valores.

Diante desse fato e sob a alegação de que a determinação de sequiestro na hipótese violava a decisão proferida na aludida ADIN $n^{\circ} 1.662$, embora esta última versasse sobre ato diverso (Instrução Normativa $n^{\circ} 11 / 97$ ), praticado por ente diverso (TST) e fundado em redação anterior da Carta Constitucional, o Governador do Distrito Federal ajuizou a reclamação.

Em seu exame, o Relator, Ministro Maurício Correa, após invocar outros quatro casos semelhantes em que o STF havia empreendido raciocínio idêntico, defendeu a necessidade de preservar a autoridade da "exegese constitucional fixada pela Corte", de seus "motivos determinantes", e não "o teor formal apenas da parte dispositiva do acórdão", seguindo-se, então, um amplo debate entre os Ministros e, finalmente, a decisão, por maioria, pela qual a reclamação foi admitida e julgada procedente, reconhecendo-se que a determinação de seqủestro, no caso, efetivamente violara a autoridade da decisão proferida pelo Supremo na ADIN $n^{\circ} 1.662$, e afir- 
mando-se, por conseguinte, a eficácia vinculante ou transcendente da fundamentação.

Outros julgados sucederam esse último, sendo de se registrar recente decisão proferida em 11-03-05, na Reclamação $n^{\circ} 2.986$, relatada pelo Ministro Celso Mello e divulgada pelo Informativo STF $\mathrm{n}^{\circ} 379$, sinalizando uma estabilização do entendimento da maioria da Corte em tal sentido:

"O litígio jurídico-constitucional suscitado em sede de controle abstrato (ADI 2.868/PI), examinado na perspectiva do pleito ora formulado pelo Estado de Sergipe, parece introduzir a possibilidade de discussāo, no âmbito deste processo reclamatório, do denominado efeito transcendente dos motivos determinantes da decisão declaratória de constitucionalidade proferida no julgamento plenário da já referida $A D I 2.868 / P I$, Rel. p/ o acórdão Min. JOAQUIM BARBOSA. Cabe registrar, neste ponto, por relevante, que o Plenário do Supremo Tribunal Federal, no exame final da Rcl 1.987/DF, Rel. Min. MAURÍCIO CORREA, expressamente admitiu a possibilidade de reconhecer-se, em nosso sistema jurídico, a existência do fenômeno da "transcendência dos motivos que embasaram a decisão" proferida por esta Corte, em processo de fiscalização normativa abstrata, em ordem a procla. mar que o efeito vinculante refere-se, também, à própria "ratio decidendi", projetando-se, em conseqüência, para além da parte dispositiva do julgamento, "in abstracto", de constitucionalidade ou de inconstitucionalidade. Essa visão do fenômeno da transcendência parece refletir a preocupação que a doutrina vem externando a propósito dessa específica questão, consistente no reconhecimento de que a eficácia vinculante não só concerne à parte dispositiva, mas refere-se, também, aos próprios fundamentos determinantes do julgado que o Supremo Tribunal Federal venha a proferir em sede de controle abstrato, especialmente quando consubstanciar declaração de inconstitucionalidade, (...)." 54

Mais adiante, externou o Ministro Celso Mello as razões que conduziam à conferência de tal eficácia à fundamentação, salientando que a mesma vinha se demonstrando necessária uma vez que seria fundamental garantir a exegese constitucional firmada pelo Supremo (e não apenas o dispositivo de suas decisões) para o fim de preservar sua missão de guardião da Constituição e a própria força normativa desta, evitando-se, assim, que se repetissem ao infinito atos idênticos àqueles já repelidos, a pretexto de um entendimento restritivo dos efeitos vinculantes, como se vinha verificando na prática.

“Na realidade, essa preocupação, realçada pelo magistério doutrinário, tem em perspectiva um dado de insuperável relevo político-jurídico, con-

54 Rel $n^{\circ}$ 2986, Min. Rel. Celso Mello. Informativo STF $n^{\circ}$ 379. http: www.stf.gov.br.. Acesso em 11-08-05. 
sistente na necessidade de preservar-se, em sua integralidade, a força normativa da Constituição, (...). (...) assume papel de fundamental importância a interpretação constitucional derivada das decisões proferidas pelo Supremo Tribunal Federal, cuja função institucional, de 'guarda da Constituição' (CF, art. 102, 'caput'), confere-lhe o monopólio da última palavra em tema de exegese das normas positivadas no texto da Lei Fundamental, como tem sido assinalado, com particular ênfase, pela jurisprudência desta Corte Suprema: '(...) A interpretação do texto constitucional pelo STF deve ser acompanhada pelos demais Tribunais. (...) A não-observância da decisão desta Corte debilita a força normativa da Constituição. (...).' (RE 203.498-AgR/DF, Rel. Min. GILMAR MENDES - grifei)." "s5

Com base em tais argumentos, foi deferida liminar na Reclamação, determinando-se a suspensão da eficácia do ato que a ensejou.

Verifica-se, portanto, que, no Brasil, ao menos no que respeita ao controle concentrado, o problema referente ao limite e ao conteúdo da regra vinculante constitui questão submetida a um debate cuidadoso e sua solução está se consolidando com o tempo e tendo por base a experiência prática da Corte Suprema no âmbito da jurisdição concentrada.

Pode-se afirmar, ainda, que hoje se reconhece que o que possui eficácia vinculante é a exegese constitucional firmada pelo Supremo Tribunal Federal, e não apenas o dispositivo de sua decisão, sendo necessário recorrer à fundamentação para identificá-la, daí falar-se em transcendência (sobre a parte dispositiva) dos motivos que embasaram a decisão e dos princípios por ela consagrados.

Além disso, tendo em vista que esse entendimento resulta da percepção da Corte Constitucional sobre a conformação que deve ser dada aos efeitos vinculantes a fim de que estes possam atender às finalidades para as quais foram criados, é possível que tal critério venha a ser utilizado pelo STF igualmente para a formulação do teor da súmula vinculante, projetando em suas proposições a exegese consagrada na fundamentação de seus acórdãos paradigmas, desde que necessária à solução do caso.

Concluída a abordagem no que concerne à extração da regra vinculante no Brasil, passa-se a examinar como vem trabalhando sua jurisprudência com a noção de distinguish, ou seja, de distinção entre casos para fins de aplicação (ou não) de uma decisão, afirmada em um precedente, a um novo caso concreto a ser decidido.

\subsection{Distinção entre precedente e caso a ser decidido}

Como exposto acima, o distinguishing corresponde, no direito norte-americano, à atividade intelectual que resultará na não aplicação de um precedente, a despeito de o caso concreto subsumir-se no âmbito normativo de seu holding, ao argumento

Idem, ibidem. 
de que os fatos relevantes (material facts) ou a lógica da decisão precedente não lhe são aplicáveis, em virtude de suas peculiaridades.

No caso das súmulas brasileiras, a questão do distinguish adquire alguns contornos especiais. É que, nestas, como já observado, a regra vinculante é extraída a partir de diversos paradigmas (espécie de line of precedentes) e formulada sem especificar os fatos que a ensejaram, de modo que, para desenvolvimento de uma argumentação consistente no sentido de se efetuar uma distinção entre o caso a ser decidido e aqueles que geraram as súmulas, tornar-se-á necessário identificar os fatos relevantes para a decisão de cada acórdão paradigma a que a súmula faz remissão e confrontá-los entre si, de modo a efetivamente traçar um padrão de diferenciação.

De todo modo, sem dúvida alguma, a noção de distinguish não é estranha ao sistema brasileiro. Um exemplo de sua aplicação pode ser encontrado na decisão proferida pelo STF na Reclamação $n^{\circ} 1.132-1-\mathrm{RS}^{56}$, relevante por demonstrar inclusive a importância de tal conceito para a articulação entre os sistemas de controle concentrado e de controle difuso de constitucionalidade.

A mencionada Reclamação fora ajuizada pelo Instituto de Previdência do Estado do Rio Grande do Sul - IPERGS, sob a alegação de que o Juízo da $2^{\mathrm{a}}$ Vara de Fazenda Pública da Comarca de Porto Alegre desrespeitara a autoridade da decisão proferida na $\mathrm{ADC} \mathrm{n}^{\circ} 4-\mathrm{DF}$.

A ADC $n^{\circ} 4-\mathrm{DF}$, por sua vez, tem por objeto a declaração de constitucionalidade do art. $1^{\circ}$ da Lei $n^{\circ} 9.494 / 97^{57}$, que vedou o deferimento de qualquer medida de

56 Ag. Reg. na Rcl. n 1.132-1-RS, Min. Rel. Ceiso de Mello, decisão de 23-03-00, DJ de 04-04-03, p. 39, unânime.

57 O art. $1^{\circ}$ da Lei 9.494/97 tem a seguinte redação: "Art. $1^{\circ}$ Aplica-se à tutela antecipada prevista nos arts. 273 e 461 do Código de Processo Civil o disposto nos arts. $5^{\circ}$ e seu parágrafo único e $7^{\circ}$ da Lei 4.348, de 26 de junho de 1964, no art. $1^{\circ}$ e seu $\$ 4^{\circ}$ da Lei $n^{\circ} 5.021$, de 9 de junho de 1966, e nos arts. $1^{\circ}, 3^{\circ}$ e $4^{\circ}$ da Lei $n^{\circ} 8.437$, de 30 de junho de 1992". Já os citados dispositivos da Lei 4.348/64 dispõem: "Art. $5^{\circ}$. Não será concedida a medida liminar de mandados de segurança impetrados visando à reclassificação ou equiparação de servidores públicos, ou à concessão de aumentos ou extensão de vantagens. Parágrafo único. Os mandados de segurança a que se refere este artigo serão executados depois de transitada em julgado a respectiva sentença"; "Art. $7^{\circ}$. $O$ recurso voluntário ou 'ex officio', interposto de decisão concessiva de mandado de segurança que importe outorga ou adição de vencimento ou ainda reclassificação funcional, terá efeito suspensivo". Dispōem, por sua vez, o art. $1^{\circ}$, caput, e seu parágrafo $4^{\circ}$, da Lei 5.021/66: "Art. $1^{\circ}$. $O$ pagamento de vencimentos e vantagens pecuniárias asseguradas, em sentença concessiva de mandado de segurança, a servidor público federal, da administração direta ou autárquica, e a servidor público estadual e municipal, somente será efetuado relativamente às prestações que se vencerem a contar da data do ajuizamento da inicial. (...). $\$ 4^{\circ}$. Não se concederá medida liminar para efeito de pagamento de vencimentos e vantagens pecuniárias". Estabelecem, por fim, os arts. $1^{\circ}, 3^{\circ}$ e $4^{\circ}$ da Lei 8.437/92, que: “Art. $1^{\circ}$. Não será cabivel medida liminar contra atos do Poder Público, no procedimento cautelar ou em quaisquer outras ações de natureza cautelar ou preventiva, toda vez que providência semelhante não puder ser concedida em ações de mandado de segurança, em virtude de vedação legal. (...). \& $3^{\circ}$. Não será cabivel medida liminar que esgote, no todo ou em qualquer parte, o objeto da açāo"; "Art. $3^{\circ}$. O recurso voluntário ou ex officio, interposto contra sentença em processo cautelar, proferida contra pessoa jurídica de direito público ou seus agentes, que importe em outorga ou adição de vencimentos ou de reclassificação funcional, 
antecipação de tutela contra a Fazenda Pública que tivesse por escopo a concessão de aumentos ou a extensão de vantagens, a reclassificação ou equiparação de servidores públicos, o pagamento de vencimentos ou vantagens a servidores, ou o deferimento de tais medidas quando esgotassem, no todo ou em parte, o objeto da ação.

No bojo da $\mathrm{ADC} \mathrm{n}^{\circ}$ 4-DF, o Supremo Tribunal Federal, entendendo plausível a constitucionalidade da norma, deferiu liminar (provida de efeitos vinculantes), com o fim de suspender quaisquer decisões de antecipação de tutela "que tivessem por pressuposto a constitucionalidade ou inconstitucionalidade do artigo $I^{\circ}$ da Lei 9.494/97". Assim, por tal liminar, proibiu-se o deferimento de qualquer antecipação de tutela contra a Fazenda Pública que envolvesse uma hipótese vedada pelo art. $1^{\circ}$ da Lei 9.494/97.

No caso que ensejou a aludida Reclamação n 1.132-1-RS, o Juízo da $2^{\text {a }}$ Vara de Fazenda Pública da Comarca de Porto Alegre havia deferido antecipação de tutela contra o IPERGS para o fim de determinar o pagamento de complementação do valor de pensão devida a uma viúva de servidor público. Tratava-se, portanto, de hipótese, ao menos aparentemente, subsumível à vedação constante da liminar proferida na $\mathrm{ADC} \mathrm{n}^{\circ} 4$.

Processada a reclamação, a liminar requerida em seus autos (para o fim de suspender a antecipação de tutela contra a qual investia) foi, contudo, indeferida, ao argumento de que o caso específico possuía peculiaridades que o distinguiam da situação de fato genérica subjacente àquela com base na qual foi proferida a liminar na $\operatorname{ADC~} n^{\circ} 4$, a saber: (a) que, no caso que gerou a reclamação, a referida viúva beneficiada pela antecipação de tutela tinha oitenta e seis anos e precisava do valor, correspondente a verba alimentar; e (b) que a tese com base na qual pleiteava a complementação de pensão encontrava suporte em maciça jurisprudência da própria Corte Constitucional.

Além disso, consignou o Ministro Néri da Silveira em seu voto, a título de "fundamento adicional" (claramente um obiter dicta), entendimento no sentido de que a decisão da $\mathrm{ADC} \mathrm{n}^{0} 04$ não se aplicaria às hipóteses de pensões previdenciárias, por se referir exclusivamente a vantagens a serem pagas a servidor público (e não a pensionista de servidor público).

De todo modo, nota-se que o exemplo acima, ao menos no que respeita à fundamentação principal, realmente adotada pela Corte, pode ser enquadrado em duas das hipóteses já elencadas, de forma exemplificativa, como situações em que se reconhece a possibilidade de distinguish no direito norte-americano.

Primeiramente, poder-se-ia enquadrar a situação acima como hipótese de distinguish fundada na constatação da existência de peculiaridades fáticas (idade avan-

terá efeito suspensivo"; "Art. $4^{\circ}$. Compete ao presidente do tribunal, ao qual couber o conhecimento do respectivo recurso, suspender, em despacho fundamentado, a exécução da liminar nas ações movidas contra o Poder Público ou seus agentes, a requerimento do Ministério Público ou da pessoa jurídica de direito público interessada, em caso de manifesto interesse público ou de flagrante ilegitimidade, e para evitar grave lesão à ordem, à saúde, à segurança e à economia públicas". 
çada da autora e existência de jurisprudência dominante em favor de sua tese) que justificam um tratamento diferenciado ao caso a ser decidido.

Poder-se-ia entender, contudo, que o distinguish se justificaria em virtude de um conflito entre normas ${ }^{58}$, uma vez que incidentes, contra a manutenção da antecipação da tutela, a norma decorrente do precedente vinculante, e, portanto, também considerações acerca de aspectos inerentes à segurança juridica e ao tratamento isonômico de todos os postulantes diante da mesma questão; e a favor da manutenção da antecipação de tutela: (a) o princípio da dignidade da pessoa humana, diante da idade avançada da autora da ação e por se tratar de prestação alimentar; (b) o direito à isonomia, em sua vertente material, eis que a autora, com oitenta e seis anos, não poderia receber tratamento idêntico aos servidores de um modo geral, aguardando até a decisão de mérito para fruir de um direito que encontrava respaldo inclusive na jurisprudência do STF; (c) o direito de acesso à justiça em seu aspecto material, diante da provável demora da lide e da idade avançada da autora, que acabaria por importar denegação da prestação da tutela jurisdicional à mesma em vida.

Para a solução do aludido conflito entre normas, seria possível afirmar que o Supremo Tribunal Federal entendeu que a norma, em regra constitucional, seria inconstitucional naquela situação concreta, por violar o princípio da dignidade da pessoa humana, o direito à isonomia e/ou o direito de acesso à justiça. Poder-se-ia afirmar, também, que o Supremo, para negar a liminar na reclamação, teria, implicitamente, ponderado valores de segurança jurídica, que o levariam à aplicação do precedente, com os demais valores constitucionais em jogo, que o conduziram a sua não aplicação. Neste passo, fica claro que as idéias de ponderação e de razoabilidade se relacionam instrumentalmente com o mecanismo de distinguish, como já assinalado acima.

Além disso, a hipótese acima é eloqüente porque demonstra que peculiaridades de fato impactam inclusive sobre o controle concentrado de constitucionalidade, por exemplo, limitando o escopo vinculante das decisões nele proferidas, controle este que a doutrina afirma se dar em abstrato.

Ilustra, ainda, como a regra emergente de uma decisão vai se construindo e se lapidando aos poucos, por um processo dialético que continua após a sua prolatação, e que envolve a corte vinculante, as cortes vinculadas, as partes e a argumentação por elas desenvolvida, com base nas peculiaridades de cada caso concreto. Assim, em virtude deste circuito contínuo que faz o precedente judicial, começando com sua enunciação na corte vinculante, passando por sua interpretação e aplicação na corte vinculada, e retornando à corte vinculante para controle, o mesmo estará sempre se reelaborando, se reformulando. ${ }^{59}$

58 A possibilidade de eiiquadramento em duas hipóteses diversas justificadoras de distinguish ocorre porque, como reconh não se dá sem considerações a respeito das circunstâncias concretas, de modo que situações de fato diversas ensejarão a incidência de normas diversas, que poderão conflitar entre si.

59 É importante observ'ar que o presente exemplo de distinguish, baseado na decisão proferida na Reclamação $n^{\circ}$ 1.132-1-RS, apresentou, posteriormente, uma evolução um tanto surpreendente. Em 


\subsection{Superação de Precedentes}

Por fim, tampouco é estranha ao sistema brasileiro a noção de superação ou de revogação de precedentes. Os pontos nodais para exame da questão aqui são aqueles pertinentes: (a) à fundamentação dos acórdãos que ensejaram tal superação; e (b) à verificação sobre ser ou não familiar ao STF efetuar ponderações entre as vantagens de alteração de precedentes e os prejuízos a serem gerados à segurança jurídica e à isonomia, como ocorre nos países do common law.

Quanto à fundamentação, no que concerne às cortes vinculadas, a superação de um precedente, ou melhor, a rejeição de um precedente da corte superior, por parte dos órgãos jurisdicionais inferiores, muitas vezes se faz de forma tácita, simplesmente ignorando-se sua regra, o que, segundo Maccormick e Summers, constitui uma ocorrência comum aos países que adotam o sistema do civil law.

Outras vezes, também, tal rejeição se expressa em diferenciações (distinguish) inconsistentes, como o caso examinado na Reclamação $n^{\circ}$ 1.987-0-DF, acima mencionada $^{60}$, prática que não se restringe aos países do civil law, tanto assim que se reconhece como uma das causas autorizadoras de overruling, no sistema norte-americano, a desfiguração da regra vinculante por distinções arbitrárias efetuadas pelas cortes vinculadas.

Entretanto, nota-se, no sistema brasileiro, por parte dos tribunais inferiores, um trabalho mais criterioso com decisões oriundas do exercício de jurisdição constitucional concentrada, possivelmente em virtude dos efeitos vinculantes de que são dotadas.

sessão plenária de 26-11-03, portanto, passados pouco mais de três anos da decisão proferida na mencionada Reclamação, ora em exame, o Supremo Tribunal Federal aprovou sobre o tema a Súmula $n^{\circ} 729$, com a seguinte redação: "A decisão na ação direta de constitucionalidade 4 não se aplica à antecipação de tutela em causa de natureza previdenciária". Um exame dos acórdãos aos quais a súmula se remete (Reclamações $\mathrm{n}^{\circ}$ 798-2-PA, 1.015-5-RJ, 1.122-4-RS, 1.014-7-RJ. R1601-3-SE e 1.257-3-RS) revela que esses julgados correspondiam a reclamaçōes em que o Tribunal manteve antecipações de tutela deferidas contra a Fazenda Pública para determinar: (a) a revisão do valor e o pagamento de pensão previdenciária; (b) a cessação de desconto de contribuição previdenciária e a sustação de redução de proventos, ambos concernentes a servidor inativo; e (c) o restabelecimento de benefício previdenciário cortado. Tais acórdãos se baseavam, essencialmente, no argumento de que a vedação de deferimento de antecipação de tutela prevista no art. $1^{\circ}$ da Lei 9.494/97 abrangeria apenas hipóteses em que esta implicasse em pagamento de vantagens $e$ vencimentos a servidores públicos, em virtude do teor literal da norma. Desses fundamentos emergiu, então, a proposição de que a vedação prevista no aludido art. $1^{\circ}$ da Lei $9.494 / 97$ não abrangeria qualquer parcela previdenciária, nem mesmo quando referente a servidores públicos inativos. De todo modo, este resultado final não infirma o valor da Reclamação 1.132-1como exemplo de distinguish efetuado pelo Supremo de modo a possibilitar uma adequada articulação entre o controle concentrado e o controle difuso, e corrobora a idéia de que o conteúdo da regra vinculante vai se reformulando, se limitando ou estendendo, aos poucos, mesmo após a prolatação da decisão, como descrito acima.

60 Item 3.1. deste trabalho. 
De todo modo, com a instituição do mecanismo da reclamação, inclusive para a hipótese de desrespeito a súmulas vinculantes, em decorrência da Emenda 45/04, é possível que o problema da rejeição de precedentes superiores pelas cortes vinculadas seja atenuado, embora se deva ressalvar aqui que a mesma é, em certa medida, saudável, auxiliando a conformação da regra vinculante de forma mais ou menos ampla de acordo com peculiaridades não previstas quando de sua formulação, evidenciando as incongruências e injustiças dos maus precedentes, portanto, criando condições para sua superação, e, de tal forma, garantindo a não petrificação do direito e a continuidade de seu desenvolvimento.

No que respeita à superação de precedentes pelo STF, o que se constata é que há, igualmente, um trabalho de fundamentação mais criterioso em sede de controle concentrado. Assim, pode-se afirmar que, atualmente, o rigor aplicado à fundamentação para superação de precedentes varia na proporção dos efeitos vinculantes destes últimos.

No que concerne a ponderações entre vantagens de alteração de precedentes e prejuízos à segurança jurídica e à isonomia, não são estranhas ao Supremo reflexões sobre consequências econômicas ou resultados políticos decorrentes de suas decisões. ${ }^{61}$ Tampouco lhe são estranhas considerações sobre a limitação dos efeitos da declaração de inconstitucionalidade como resultado de ponderações com outros bens e interesses constitucionalmente protegidos, como ocorre, por exemplo, com a preservação de decisões transitadas em julgado, a despeito da posterior declaração, em controle concentrado, da inconstitucionalidade da lei em que se fundaram, de forma a prestigiar o princípio da segurança jurídica ${ }^{62}$.

Não é, ademais, desconhecida em nosso sistema a técnica de se conferirem efeitos prospectivos às decisões declaratórias de inconstitucionalidade, de modo a mitigar efeitos negativos delas decorrentes, idéia aparentada àquela do prospective overruling.

Além disso, como salienta Luís Roberto Barroso, a mencionada técnica, que, hoje, se baseia em norma expressa no artigo 27 da Lei 9.869/99, decorreu, na origem, de construção jurisprudencial pela qual o Supremo ponderava a norma constitucional violada com as normas constitucionais que protegiam os efeitos produzidos pela lei inconstitucional, tal como boa-fé, moralidade, irredutibilidade de vencimentos, razoabilidade, mitigando o dogma dos efeitos retroativos da declaração de inconstitucionalidade ${ }^{63}$.

61 Cf. VIEIRA, Oscar Vilhena. Supremo Tribunal Federal: Jurisprudência Política. São Paulo: Malheiros, 1994, p. 117-216.

62 BARROSO, Luís Roberto. O controle de constitucionalidade no direito brasileiro: exposição sistemática da doutrina e análise crítica da jurisprudência. Op. cit., p. 92.

63 BARROSO, Luís Roberto. O controle de constitucionalidade no direito brasileiro: exposição sistemática da doutrina e análise crítica da jurisprudência. Op. cit., p. 160. 


\section{Conclusão}

O trabalho com precedentes vinculantes demanda o desenvolvimento de uma doutrina específica, que organize as ferramentas necessárias ao empreendimento de um raciocínio analógico, pelo qual se efetuará o confronto das peculiaridades do caso antecedente com as peculiaridades do caso em exame, de modo a se decidir pela aplicação (ou não) da regra oriunda do primeiro ao segundo.

No direito comparado, tais ferramentas correspondem às noções de holding (regra necessária à solução do caso), obiter dictum (considerações marginais não necessárias à solução do caso), rationale (lógica da decisão) e material facts (fatos considerados relevantes para o julgamento).

De forma bastante simplificada, é possível afirmar que um caso se individualiza por seus material facts e pela substantive reasoning (fundamentação necessária) que os liga à sua conclusão. É a partir de tais elementos que se extrai a regra vinculante do precedente.

A aplicação de um precedente é afastada quando quer seus fatos, quer sua lógica/fundamentação são muito diversos ou inaplicáveis ao caso a decidir, em virtude das peculiaridades deste último, dando ensejo ao que se denomina distinguish (distinção).

Assim, através do distinguish e, de forma geral, do trabalho empreendido inclusive pelas cortes vinculadas, a regra vinculante vai sendo reformulada, limitada, estendida, tendo vida própria, constituindo expressão do papel criativo da jurisprudência na construção do direito.

A idéia de compreensão circular do conteúdo da decisão: da parte para o todo e de volta à parte; do dispositivo da decisão para a fundamentação e o relatório e de volta ao dispositivo; da norma para os fatos e fundamentos e de volta à norma; bem como as idéias de (re)elaboração da norma à luz de cada caso concreto, conforme os fatos, argumentos e tópicos trazidos ao debate pela argumentação das partes e a ponderação dos valores envolvidos, todas, noções da nova hermenêutica e demandas da complexidade que atingiu a sociedade, se ajustam perfeitamente ao trabalho com precedentes vinculantes, que, de nenhum modo, implicam de per si em petrificação do direito.

Ao lado da abertura do sistema de vinculação, constata-se no direito comparado o condicionamento do overruling (revogação de uma decisão vinculante) à uma ponderação entre os valores que justificam o abandono do antigo precedente e valores de segurança, previsibilidade e isonomia. De tal ponderação resultará, em algumas hipóteses, a atribuição de efeitos prospectivos à decisão que revoga um precedente, de modo a mitigar as consequências negativas dela decorrentes.

Embora ainda não se encontre, no sistema brasileiro, um tratamento amadurecido e sistematizado sobre o trabalho com precedentes vinculantes, como se dá nos países da common law, é possível afirmar que se enfrentam, no Brasil, discussões que guardam correspondência com aquelas verificadas nos referidos países.

Assim, a súmula vinculante, segundo a Emenda $n^{\circ} 45 / 04$, deverá se originar de decisões reiteradas do STF sobre controvérsia constitucional atual, ensejando, então, 
a indagação sobre a metodologia adequada à extração de regras vinculantes a partir de decisões judiciais.

Tal metodologia se faz fundamental ao exercício legítimo do poder de sumular pela Corte Constitucional, seja porque as súmulas devem ser fiéis às regras decorrentes dos precedentes que as originaram, sob pena de abuso de poder de sumular, seja porque já se identificam, hoje, diversas inconsistências em súmulas editadas pelo Supremo, quando confrontałas com os julgados que lhes deram origem.

No controle concentrado, por sua vez, a resposta à questão sobre a metodologia adequada à extração de regras vinculantes a partir de decisões judiciais está em processo de estabilização, podendo-se afirmar que, atualmente, a maioria dos Ministros do STF entende que os efeitos vinculantes não se limitam à declaração de constitucionalidade ou inconstitucionalidade de determinada norma, mas também alcançam a exegese constitucional, a lógica da decisão, os fundamentos necessários, ainda que mínimos (eficácia transcendente da fundamentação), de modo que a decisão não vincula apenas quanto à (in)constitucionalidade da norma questionada, mas abrange igualmente outros atos que desrespeitem a mencionada exegese constitucional fixada pela decisão precedente.

Por outro lado, em sede de controle concentrado, meras considerações marginais constantes da fundamentação, portanto, os chamados obiter dictum não vinculam, muito embora se deva ressalvar que, no controle difuso e na edição de súmulas, a prática constitucional se distancie de tal entendimento, falhando, por vezes, em diferenciar entre as considerações marginais e os fundamentos necessários à decisão.

Assim, pode-se arriscar conceituar como regra vinculante, no sistema brasileiro, a exegese constitucional necessária à decisão judicial, extraída por um processo de compreensão circular, a partir de seu dispositivo e de seus fundamentos, e limitada pela moldura fática que individualiza o caso.

Pode-se, ainda, arriscar conceituar como considerações marginais toda e qualquer consideração desnecessária à obtenção da conclusão alcançada pela decisão judicial, que, por tal razão, não é dotada de eficácia vinculante.

Quanto à noção de distinção entre casos, pela qual, a partir de peculiaridades presentes em um e ausentes em outro se conclui pela não aplicação de um precedente, esta também não é estranha ao direito brasileiro, se efetuando, igualmente, de acordo com os aspectos de fato e de direito suscitados por cada demanda. Essa idéia, no sistema brasileiro, tem uma importante função na articulação entre o controle concentrado e o controle difuso, possibilitando o reconhecimento de inconstitucionalidade ou a não aplicação de normas declaradas constitucionais em sede de controle concentrado quando, em sede de controle difuso, se constatar que as mesmas normas, em virtude de peculiaridades do caso, importam violação a valores constitucionais predominantes em concreto.

Assim, arrisca-se conceituar distinção, no caso brasileiro, como a atividade intelectual, baseada em um raciocínio analógico, pela qual se justificará a não aplicação da regra emergente de um precedente a um caso ao qual aparentemente se aplicaria, em virtude de peculiaridades de fato e/ou de direito identificadas neste último, a partir dos argumentos e tópicos trazidos pelas partes, e ponderando-se os valores em tensão. 
No que respeita à superação de precedentes pelo STF, pode-se afirmar que $o$ rigor com que se expõe a fundamentação que a justifica varia, hoje, na proporção $e$ intensidade dos efeitos vinculantes da decisão a ser superada, e que não são estranhas à Corte Constitucional reflexões sobre consequências econômicas ou resultados políticos decorrentes de seus julgados. Quanto à restrição dos efeitos temporais de decisões que implicam na superação de precedentes, a fim de preservar valores como a segurança jurídica, trata-se de idéia familiar ao ordenamento jurídico brasileiro, a exemplo da possibilidade de se conferirem efeitos ex nunc às decisões declaratórias de inconstitucionalidade em sede de controle concentrado.

Nota-se, ademais, de todo o exposto, que o trabalho com precedentes vinculantes demanda um raciocínio analógico para o qual é fundamental a obtenção do máximo de informações sobre o caso precedente, a fim de se poder conhecer adequadamente seus fatos e sua lógica, de modo a efetuar seu confronto com o caso a decidir. Torna-se, portanto, primordial: (a) que o Tribunal Constitucional, ao proferir suas decisões, desenvolva relatórios pormenorizados sobre os fatos considerados relevantes para as mesmas ${ }^{64}$, e, bem assim, as fundamente de forma ampla, deduzindo todas as razões e considerações pertinentes; (b) que os juízes vinculados, igualmente, se dediquem a relatar pormenorizadamente os fatos relevantes e os fundamentos de suas decisões, em especial nos casos de distinção entre precedentes, de restrição e/ou de extensão de suas regras; (c) que as decisões sejam publicadas de forma imediata e completa, a fim de que se possa ter um compêndio atualizado sobre como se vem julgando cada matéria; (d) que tais publicações sejam organizadas, sistematizadas e haja ferramentas de busca eficientes e rápidas para sua pesquisa; (e) que a educação do Direito assimile estas novas demandas e métodos, e se adapte a eles, treinando adequadamente os profissionais no manejo de precedentes e reformulando seus métodos, se necessário; ( $f$ ) que os advogados e as partes, assim como os magistrados, se habilitem no trabalho com precedentes, se familiarizem com os instrumentos aptos a viabilizar uma distinção, a justificar uma revogação, a possibilitar a aplicação de um precedente anterior.

Não atendemos hoje, plenamente, a qualquer dos requisitos acima, seja em virtude da imensa sobrecarga de trabalho dos magistrados, seja porque a vinculação a precedentes foi se tornando uma realidade de forma paulatina, demandando, portanto, ajustes e um desenvolvimento acadêmico, doutrinário, correspondente. Há, assim, um grande caminho a percorrer.

Os precedentes vinculantes representam o reconhecimento do papel construtivo da jurisprudência e se destinam a conferir maior eficiência, isonomia e segurança ao sistema, gerando, contudo, normas gerais, que, como quaisquer outras, estão sujeitas a interpretação e ambigüidades. Este é o paradoxo.

O equilíbrio necessário ao sucesso em seu uso é delicado e só será alcançado com o tempo, mas um início muito desastroso pode levar à superlotação do Supremo

64 Mesmo no controle concentrado de constitucionalidade, ainda que se entenda que este se dá em abstrato, haverá sempre uma realidade subjacente à norma que inevitavelmente interferirá em sua interpretação. 
Tribunal Federal por milhares de reclamações e, como consequiência, gerar nesta sede uma jurisprudência defensiva que frustraria a efetividade do sistema, seja por não tornar eficaz o efeito vinculante das decisões, seja por permitir que este efeito se efetive em demasia, aplicando-se precedentes acriticamente a situações que não os comportam e, por conseguinte, gerando um imobilismo do direito.

O sucesso da idéia de precedentes vinculantes, por sua vez, poderá significar uma renovação de métodos, um florescimento do desenvolvimento judicial do direito, a consolidação do papel do Supremo Tribunal Federal como guardião da Constituição, uma melhor seleção das questões que efetivamente demandam debate mais profundo pela Corte Constitucional, uma renovação de paradigmas.

Como se vê, os precedentes vinculantes não são positivos ou negativos de per si. Somente a prática poderá determinar se representarão uma revolução ou um retrocesso.

\section{Referências}

ALEXANDER, Larry. "Constrained by Precedent". In: University of Southern California Law Review, 1989.

ALEXY, Robert e DREIER, Ralf. "Precedent in the Federal Republic of Gremany". In: MACCORMICK, D. Neil e SUMMERS, Robert S. (org.). Interpreting precedents: a comparative study. England: Dartmouth Publishing Company Limited e Ashgate Publishing Limited, 1997, p. 17-66.

ALVES DA SILVA, Carla Mendonça Dias. "Efeitos vinculantes das decisões dos Tribunais Superiores: uma realidade". Revista de Processo, São Paulo, v. 29, n.115, p. 164-177, maio/jun. 2004.

ÁVILA, Humberto. Teoria dos princípios: da definição à aplicação dos princípios jurídicos. 3. ed. São Paulo: Malheiros, 2004.

BARBOSA MOREIRA, José Carlos. "'Súmula vinculante' e duração dos processos”. ADV: Advocacia Dinâmica - Seleções Jurídicas, São Paulo, n.8, p. 44-45, ago. 2004.

BARROSO, Luís Roberto. Interpretação e aplicação da Constituição 5. ed. São Paulo: Saraiva, 2003.

O controle de constitucionalidade no direito brasileiro: exposição sistemática da doutrina e análise crítica da jurisprudência. São Paulo: Ed. Saraiva, 2004.

CALMON DE PASSOS, José Joaquim. "Súmula vinculante". Revista Diálogo Jurídico, Salvador: CAJ - Centro de Atualização Jurídica, n. 10, 2002. Disponível em: http://www.direitopublico.com.br. Acesso em: 29 maio 2005.

CANARIS, Claus-Wilhelm. Pensamento sistemático e conceito de sistema na ciência do direito. Lisboa: Fundação Calouste Gulbenkian, 2002.

CARMARGO, Margarida Maria Lacombe. Hermenêutica e Argumentação: Uma Contribuição ao Estudo do Direito. 3. ed. Rio de Janeiro: Ed. Renovar, 2003.

COLE, Charles D.. "Stare decisis na cultura jurídica dos Estados Unidos. O sistema de precedente vinculante do common law". Tradução: Maria Cristina Zucchi. Revista dos Tribunais, São Paulo, v. 87, n. 752, p. 11-21, jun. 1998. 
DINAMARCO, Cândido Rangel. "Súmulas Vinculantes". Revista Forense, Rio de Janeiro, v. 95, n. 347, p. 51-65, jul./set. 1999.

GRAU, Eros Roberto. "Sobre a produção legislativa e sobre a produção normativa do direito oficial: o chamado "efeito vinculante"". Revista Trimestral de Direito Público, São Paulo, n. 16, p. 31-38, 1996.

GRECO, Leonardo. "Novas súmulas do STF e alguns reflexos sobre o mandado de segurança". Revista Dialética de Direito Processual, São Paulo, n. 10, p. 44-54, jan. 2004.

LAMY, Eduardo de Avelar. "Súmula vinculante: um desafio". Revista de Processo, São Paulo, v. 30, n.120, p. 112-137, fev. 2005.

LINS E SILVA, Evandro Cavalcanti. "Crime de hermenêutica e súmula vinculante". Revista Consulex, Rio de Janeiro, v. 1, n. 5, p. 6-8, 1997.

. "A questão do efeito vinculante". Revista da $O A B$, Brasília, v. 25, n. 61, p. 53-58, jul./dez. 1995.

MACCORMICK, D. Neil e SUMMERS, Robert S. "Further General Reflections and Conclusions". In: MACCORMICK, D. Neil e SUMMERS, Robert S. (org.). Interpreting precedents: a comparative study. England: Dartmouth Publishing Company Limited e Ashgate Publishing Limited, 1997, p. 531-550.

MALTZ, Earl. "The Nature of Precedent". In: North Carolina Lav Review, vol. 66, 1988.

MARSHALL, Geoffrey. "What is binding in a precedent". In: MACCORMICK, D. Neil e SUMMERS, Robert S. (org.). Interpreting precedents: a comparative study. England: Dartmouth Publishing Company Limited e Ashgate Publishing Limited, 1997, p. 503-518.

MENDES, Gilmar Ferreira. "O efeito vinculante das decisões do Supremo Tribunal Federal nos processos de controle abstrato de normas". Revista Jurídica Virtual, vol. 1, n. 4, agosto 1999. Disponível em:

https://www.planalto.gov.br/ccivil_03/revista/Rev_04/efeito_vinculante.htm. Acesso em: 30 jun. 2005.

. Jurisdição constitucional. 4.ed. São Paulo: Editora Saraiva, 2004.

MONAGHAN, Henry Paul. "Stare decisis and constitutional adjudication". In Columbia Law Review, vol, 88, 1988.

MOREIRA, José Carlos Barbosa. "A redação da Emenda Constitucional n 45 (Reforma da Justiça)". Revista Forense, Rio de Janeiro, v. 101, n.378, p. 39-46, mar./abr. 2005.

NORTHFLEET, Ellen Gracie. "Ainda sobre o efeito vinculante". Revista de Informação Legislativa, Brasilia, v. 33, n. 131, p. 133-134, jul./set. 1996.

PEÑA, Eduardo Chemale Selistre. "Reforma do Judiciário: a polêmica em torno da adoção das súmulas vinculantes e a solução oferecida pelas súmulas impeditivas de recursos". Revista de Processo, São Paulo, v. 30, n.120, p. 77-94, fev. 2005.

RE, Edward D. "Stare decisis". Tradução: Ellen Gracie Northfleet Revista de Processo n. 73, p. 47-54, jan./mar. 1994.

SARMENTO, Daniel. A Ponderação de Interesses na Constituição. Rio de Janeiro: Lumen Juris, $3^{\mathrm{a}}$ ed., 2003. 
SCAFF, Fernando Facury e MAUÉS, Antônio G. Moreira. "A trajetória brasileira em busca do efeito vinculante no controle de constitucionalidade". In: WAMBIER, Teresa Arruda Alvim et al. (org.) Reforma do Judiciário: Primeiros ensaios críticos sobre a EC n. 45/2004. São Paulo: Ed. Revista dos Tribunais, 2005, p. 225-242.

SCARTEZZINI, Ana Maria Goffi. "A súmula vinculante - O contraditório e a ampla defesa”. Revista de Processo, São Paulo, v. 30, n.120, p. 68-76, fev. 2005.

SILVA, Celso de Albuquerque. Do Efeito Vinculante: sua Legitimação e Aplicação. Rio de Janeiro: Lúmen Júris, 2005.

STRECK, Lênio Luiz. "O efeito vinculante e a busca da efetividade da prestação jurisdicional - da Revisão Constitucional de 1993 à reforma do Judiciário (EC 45/04)". In: AGRA, Walber de Moura (org.). Comentários à reforma do Poder Judiciário, Rio de Janeiro: Ed. Forense, 2005, p. 152-160.

. Jurisdição Constitucional e Hermenêutica: uma nova crítica do direito. 2. ed. Rio de Janeiro: Ed. Forense, 2004.

. "Efeito vinculante: desmi(s)tificações necessárias acerca dos projetos de reforma do Judiciário". Revista da Femargs n. 1. Disponível em: http://www.femargs.com.br/revista01_streck.html. Acesso em: 25 jun. 2005.

SUMMERS, Robert S.. "Departures from precedents". In: MACCORMICK, D. Neil e SUMMERS, Robert S. (org.). Interpreting precedents: a comparative study. England: Dartmouth Publishing Company Limited e Ashgate Publishing Limited, 1997, p. 519-530.

"Precedent in the United States (New York State)". In: MACCORMICK, D. Neil e SUMMERS, Robert S. (org.). Interpreting precedents: a comparative study. England: Dartmouth Publishing Company Limited e Ashgate Publishing Limited, 1997, p. 355-406.

TAVARES, André Ramos. Reforma do Judiciário no Brasil pós-88: (des)estruturando a justiça: comentários completos à Emenda Constitucional n. 45/04. São Paulo: Ed. Saraiva, 2005.

TEIXEIRA, Sálvio de Figueiredo. "A súmula e sua evolução no Brasil." Biblioteca Digital Jurídica do Superior Tribunal de Justiça. Disponível em: http://bdjur.stj.gov.br/dspace/index.jsp. Acesso em: 29 jun. 2005.

VELLOSO, Carlos Mário da Silva. "Poder Judiciário: controle externo e súmula vinculante”. Revista do Advogado, São Paulo, v. 24, n.75, p.23-27, abr. 2004.

VIEIRA, Oscar Vilhena. Supremo Tribunal Federal: Jurisprudência Política. São Paulo: Malheiros, 1994, p. 117-216. 